\title{
La representación de la vida cotidiana de las mujeres de las clases bajas en los libros de adab: aproximación a partir de un ejemplar de época nazarí (s. VIII/XIV)*
}

\author{
The Picture of Lower-Class Women's Everyday Life in Adab Books: \\ An Approach Based on a Work from the Nasrid Period (8th/14th c.)
}

\author{
Desirée López-Bernal \\ Universidad de Granada \\ ORCID iD: https://orcid.org/0000-0002-9756-9062
}

\begin{abstract}
Resumen
El objetivo del presente trabajo es rastrear en los libros de adab imágenes literarias de la vida cotidiana de las mujeres árabes-musulmanas de las clases bajas en entornos urbanos, puestas en relación con los conocimientos que poseemos al respecto a partir de fuentes de otra naturaleza. El estudio se ha llevado a cabo tomando como fuente principal un ejemplar del periodo nazarí, los Hadā iq al-azāhir de Ibn 'Āṣim. No obstante, con el fin de ofrecer un panorama más amplio, la investigación se apoya necesariamente en otras obras del género del periodo premoderno, compuestas en distintas épocas y lugares. En conjunto, aportamos una serie de textos y referencias no utilizados hasta ahora en estudios sobre el tema. Tras su análisis, se obtiene que las representaciones literarias que ofrecen sus anécdotas confirman la información en las diversas parcelas que comprende el tema objeto de estudio obtenida hasta el momento de fuentes históricas o tratados de derecho o hisba. Al mismo tiempo, estas obras literarias presentan un elevado interés en tanto que la mayoría de personajes femeninos que aparecen en sus anécdotas pertenecen a las clases populares y en ellas se representan sus comportamientos en la vida cotidiana. En la prosa de $a d a b$, apenas se transmite una separación entre espacios masculinos y femeninos en las ciudades. Los relatos muestran a aquellas mujeres realizando diversas actividades fuera del ámbito doméstico y nos acercan a las relaciones que establecieron con los hombres desde dentro y fuera de sus viviendas.
\end{abstract}

Palabras clave: mujeres; vida cotidiana; al-Andalus; $a d a b$; literatura nazarí; Granada nazarí.

\begin{abstract}
The aim of this paper is to identify literary pictures of everyday life of lower-class Arab-Muslim women in urban contexts in $a d a b$ books, relating them to the knowledge we have about them through other kinds of sources. The study has been mainly based on Ibn 'Āṣim's Hadā'iq al-azāhir, an adab work of the Nasrid period. However, in order to provide a broader scope, it has also been imperative to examine other $a d a b$ books from the pre-modern era, composed in different periods and places. Altogether, we contribute with a number of texts and references not yet used in studies on the subject. Their analysis results in the conclusion that the literary representations contained in their anecdotes confirm the so-far available information on lower-class women, mostly originated from historical sources, as well as from law and hisba treatises. The particular interest of these anecdotes lies in the fact that most of their female characters belong to the popular classes and their behaviour in everyday life is clearly depicted throughout their plots. Regarding the physical places in which these women led their lives, in adab prose we can hardly perceive any separation between male and female spaces in the cities. Relevant stories show humble women performing diverse activities outside the domestic sphere and establishing relationships with men from inside and outside their homes.
\end{abstract}

Key words: women; everyday life; al-Andalus; adab; Nasrid literature; Nasrid Granada.

Cómo citar / Citation: López-Bernal, Desirée, "La representación de la vida cotidiana de las mujeres de las clases bajas en los libros de adab: aproximación a partir de un ejemplar de época nazarí (s. VIII/XIV)”, Al-Qanțara, 42, 2 (2021), e20. doi: https://doi.org/10.3989/alqantara.2021.017.

Recibido: 30/11/2020; Aceptado: 30/06/2021; Publicado: 14/01/2022

* Este trabajo es fruto del proyecto de Investigación I+D+i de Excelencia "La mujer nazarí y meriní en las sociedades islámicas del Mediterráneo medieval (siglos xiii-xv). Poder, identidad y dinámicas sociales” -NAZAMER- (Ref.: HAR2017-88117-P), financiado por el Ministerio de Economía y Competitividad, y la Agencia Estatal de Investigación (http://nazamer.ugr.es/). 


\section{Las mujeres de las clases bajas en los libros de adab. El caso de la literatura nazarí y los Hadā iq al-azāhir}

Mi interés en este trabajo se centra en rescatar de la literatura de $a d a b$ construcciones literarias de las vidas cotidianas de las mujeres árabes pertenecientes a las clases sociales bajas de la sociedad árabe-islámica premoderna, por ser esta categoría de mujeres aquella sobre la cual contamos con menos información, en general, y menos detallada ${ }^{1}$. El foco se centrará en aquellas que habitaron espacios urbanos, con los que se entiende que este género literario - producto y partícipe de la vida refinada en las urbesguarda un estrecho vínculo. En esta dirección he interpretado la ausencia de especificaciones que relacionen a las protagonistas de los relatos con el ámbito rural, tales como su condición de mujeres beduinas o las referencias a entornos rurales como localización de las anécdotas.

Como es costumbre en este tipo de libros, los hombres de letras introducen a su público receptor en un catálogo bien diverso de materias profanas sirviéndose de relatos de no muy dilatada extensión - la mayoría piezas de unas pocas líneas-, buena parte de ellos de carácter ameno. Los materiales de tipo humorístico dan el relevo a los más serios a propósito de cada asunto y, así, los capítulos y epígrafes se culminan con apartados específicos de anécdotas sobre el tema, práctica que es común a las obras del género ${ }^{2}$.

Tal y como se ha puesto de manifiesto en más de una ocasión, el valor documental de estas fuentes es limitado en lo que se refiere a la reconstrucción de la realidad social de los múltiples grupos humanos que se dan cita en ellas. De estas obras en las que - como señalaba - el humor juega un papel determinante, es posible extraer representaciones o imágenes literarias, sujetas, eso sí, a los cánones del género y de la

\footnotetext{
1 Manuela Marín reflejaba esta situación cuando afirmaba que «las mujeres que aparecen en las fuentes andalusíes son, mayoritariamente, miembros de las capas superiores de la sociedad». Cf., Marín, Mujeres en al-Andalus, p. 29.

2 La costumbre de situar los materiales jocosos en la parte final de los capítulos se advierte fácilmente en obras como Natr al-durr de al-Ābī (m. 421-422/1030-1031 o 432/1040) o al-Tadkira al-hamdūniyya de Ibn Hamdūn (m. 562/1166). En al-'Iqd al-farìd de Ibn 'Abd Rabbihi (m. 328/940), las anécdotas y chistecillos se entremezclan en cada capítulo con el contenido menos jovial, si bien el libro de la segunda perla sobre las bromas y los chistes (al-lu 'lu'a al-țāniya fì l-fukāhāt wa-l-mulah) sirve de colofón a la obra.
}

hilaridad y la comicidad que persigue el humor ${ }^{3}$. No obstante, no es posible obviar que tales representaciones tienen como referente indiscutible la realidad extratextual.

La lectura - muchas veces entre líneas - de sus ejemplares nos brinda ricos materiales que nos acercan desde el prisma de un género literario enciclopédico, con la voluntad de instruir a la par que entretener, a casi todas las parcelas de las vidas de las mujeres. Para tratar de asomarnos a la representación de algunas de ellas en este tipo de obras, he tomado como fuente principal los Hadā'iq al-azāhir de Abū Bakr ibn 'Āṣim (m. 829/1426), estandarte del adab al-fukāha en al-Andalus, compuesta por este jurista, hombre de Estado y literato granadino en honor del emir nazarí Yūsuf II (g. 793794/1391-1392). He rastreado, además, varias obras más del mismo género, fuera del ámbito espacial y temporal marcado en el subtítulo del presente artículo, con la intención de complementar y completar la información que aportan los relatos reunidos por el granadino.

La tónica general en las narraciones que constituyen las obras de la prosa de $a d a b$ es que los personajes que las protagonizan se presenten de forma escueta y bastante vaga en el caso de aquellos que constituyen tipos o que representan a colectivos, desprovistos de identidad y sobre los que no se proporcionan más detalles que construyan una mínima descripción de los mismos. Sucede con las mujeres - sin más precisiones - que salpican estos libros, las cuales resultan no solo desprovistas de identidad propia, sino también indeterminadas: cada una de ellas es una mujer cualquiera, lo que acentúa si cabe más su falta de identidad. En muy pocas ocasiones nos topamos con descripciones detalladas de personajes femeninos. Cuando las hay, suelen aparecer en relatos de corte amoroso y de mayor extensión, y las descripciones se ciñen a aspectos físicos, encaminados a subrayar los rasgos que configuran su belleza ${ }^{4}$. En caso de aportar algún mínimo detalle sobre su identidad, la secuencia más habitual se limita al uso

3 En este mismo sentido han escrito, entre otros, Hämeen-Anttila, "Some Notes on Women", p. 133; Ghersetti, "La représentation des pique-assiette", p. 214.

4 Ver como ejemplos Ibn 'Āṣim, Hadā'iq al-azāhir, pp. 197-198, trad. López Bernal, El libro de los huertos, pp. 253255 (n 680); al-Ibšīhī, al-Mustatraf, vol. 2, p. 190, trad. Rat, al-Mostatraf, vol. 2, pp. 405-406. El primero de los relatos constaba previamente en Ibn 'Abd Rabbihi, Kitāb al- 'Iqd alfarìd, vol. 6, pp. 411-413 (relato completo en pp. 411-416). 
del sustantivo «una mujer» seguido de un adjetivo calificativo, de una ị̂âfa (zawğat/ibnat...) o de una construcción preposicional con los que, la mayoría de las veces, se alude a una cualidad física, moral o intelectual: una mujer hermosa (imra'a ğamīla), una mujer deslenguada (imra'a māğina), una mujer elocuente (imra'a min al-bulag $\left.\bar{a} \bar{a}^{\prime}\right)$, etcétera ${ }^{5}$.

Todas las féminas rescatadas de las fuentes que ocuparán las siguientes páginas son, por tanto, «mujeres» sin más apelativos, lo que nos lleva a relacionarlas con las clases populares $\left(a l-{ }^{\prime} a m m a\right)$ y a otorgarles la condición de libres, puesto que - de no serlo- la referencia a ellas se habría hecho especificando su estatus de esclavas. Lo mismo ocurre en relación con su confesión religiosa - musulmana en todos los casos dado que no consta ninguna otra precisión-, o con su origen étnico, que debemos presuponer árabe mientras no consten otras especificaciones. He dejado a un lado las noticias conectadas con el mundo rural, por no contar la fuente principal objeto de estudio con muestras que representen aspectos cotidianos de las vidas de las mujeres. Ante la falta de una localización precisa de los relatos y/o de alusiones a personajes o contextos fuera del ámbito urbano, este último se ha entendido como el preferente, por el motivo que señalaba en el párrafo inicial de este artículo.

La frecuente y mayoritaria presencia de mujeres de los estratos bajos de la sociedad árabe-islámica se perfila como una característica propia de la literatura de $a d a b$, salvo ciertas excepciones que se mencionan un poco más adelante. Puede ser consecuencia de que en ella se integra y concede un amplio espacio al humor, elemento que conecta este género culto con el pueblo, de donde precisamente emana una porción considerable de sus relatos y anécdotas y en el que estos encuentran parte de su inspiración ${ }^{6}$.

\footnotetext{
5 Otra cuestión es la de los espacios que se reservaron a las mujeres en estas obras y a su clasificación en ellas, la cual atiende a su género, mientras que la configuración de los capítulos y epígrafes que tienen que ver con los hombres se lleva a cabo en virtud de sus cualidades morales e intelectuales o de su categoría profesional. Ver Malti-Douglas, Woman's Body, p. 31 .

6 Como llamaba la atención Joseph Sadan y él mismo demostró en varios de sus trabajos, el flujo entre la culta prosa de $a d a b$ y la literatura y la tradición orales fue bidireccional. Ver Sadan, "Hārūn al-Rashīd and the Brewer", pp. 1-6 y "Conflicting tendencies". La difusión de un relato en ambos canales contribuyó sin duda a que, en muchos casos, hoy nos encontremos ante cuentos de naturaleza folclórica.
}

De cuantas vieron la luz en el periodo nazarí, la obra de Ibn 'Āṣim es la única del género del $a d a b$ en la que se advierte una presencia femenina notable y de la que podemos extraer noticias relacionadas con mujeres de las capas bajas de la sociedad árabe-islámica, como se apreciará en adelante. Otro ejemplar de $a d a b$ del mismo periodo, el Kitāb al-zaharāt al-mantūura de Ibn Simāk al-'Āmilī (m. primera mitad s. IX/XV), no cuenta $-\mathrm{y}$ en esto coincide con el del primero- con uno o varios capítulos que versen sobre mujeres, algo que sí ocurre en otros libros del género, especialmente en los de corte más enciclopédico. La presencia de las mujeres en esta obra sobre el gobierno y la política, destinada a educar a los príncipes nazaríes, se reduce a cuatro de las cien flores que lo integran, que nos muestran a dos mujeres ancianas (flores $\mathrm{n}^{\circ} 38 \mathrm{y} \mathrm{n}^{\circ} 39$ ), una esclava (flor $\mathrm{n}^{\mathrm{o}} 40$ ) y una mujer que entrega el dinero de su marido a su amante (flor $\left.\mathrm{n}^{0} 70\right)^{7}$.

En cuanto a las mujeres protagonistas de los relatos de los Hadáa iq al-azāhir, en mi tesis doctoral detecté la intervención de personajes femeninos en, al menos, 236 relatos del corpus de 1246 que componían la traducción parcial al español realizada en ese momento, lo que equivalía a algo más de un $18 \%$ del total. Sin embargo, la relevancia de la presencia femenina en ellos no reside tanto en las cifras, como en el valor de buena parte de sus aportaciones.

Las mujeres anónimas son mayoría en la obra de Ibn 'Āṣim que, en ese sentido, sigue la tónica de los ejemplares del género, tal y como se ha señalado. Los personajes femeninos con identidad - todos orientales, salvo al-Rumaykiyya - pertenecen principalmente a la élite social (al-ḩāșa) y/o se movieron en un ambiente cortesano o más elevado. Libres o esclavas, casi todas ellas deben su pervivencia en obras como esta - así como en fuentes de otra naturaleza- a su relación con personajes masculinos ${ }^{8}$. Por su parte, las mujeres anónimas que protagonizan relatos en los Hadā'iq al-azāhir son mayoritariamente libres y proceden del pueblo llano (al- 'àmma $)^{9}$.

\footnotetext{
Ibn Simāk, Kitāb al-zaharāt al-manțūra, (1979-1980), pp. 75-76 y (1981-1982), pp. 9 y 36.

Ver Marín, "Las mujeres de las clases sociales superiores", p. 105.

$9 \quad$ Esta situación se debe a las características específicas de los Hadā' iq al-azāhir en tanto producto de al-adab al-fukāhī y que, además, presta singular atención a lo popular. Contrasta con lo que suele ocurrir en fuentes históricas, bio-bibliográficas e, incluso, otros libros de $a d a b$ de temática cortesana (como

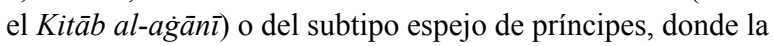
presencia de individuos de las clases bajas es menor.
} 
Junto a esta mayoría también hay esclavas ( $a m a$ l imā', ' abdal 'abdāt, ğāriya/ğawārin) y cantoras (qayna/ qiyān), a las que se relaciona con ambientes más refinados.

Una doble dificultad insalvable con la que nos toparíamos si pretendiéramos llevar a cabo un estudio de la representación de las mujeres del pueblo llano de la sociedad nazarí a partir del repertorio de Ibn 'Āṣim es, de una parte, el hecho de que la práctica totalidad de esta suerte de anécdotas, cuyos protagonistas son individuos anónimos o representantes de colectivos humanos y sociales, no están contextualizadas. Esto es, en esta y otras obras de las mismas características apenas contamos con alusiones espaciales y - en menor medida todavía - temporales, que hagan posible relacionarlas con un entorno y una época determinadas. Por otro lado, no hay que perder de vista la estratificación de esta literatura - sobre la que llamaba la atención Charles Pellat ${ }^{10}$-, más aún en tanto en cuanto nos encontramos ante una representante tardía. En este sentido, otra de las señas de identidad del $a d a b$ es la composición de sus obras a partir aunque no exclusivamente- de la recolección de materiales en la tradición escrita previa, pues precisamente con ello podía demostrar el $a d \bar{i} b$ su bagaje cultural y transmitirlo a su creación, lo cual es razón de ser del género. De modo que, el viaje de los relatos desde las fuentes más antiguas por buena parte del extenso corpus de libros que componen el género hace que sea tarea ardua separar los incorporados por el compositor de la obra en cuestión de aquellos otros asumidos de la tradición textual que le precede ${ }^{11}$.

Por lo tanto, el grueso de las noticias que ofrecen estas fuentes y de las que me serviré en el presente trabajo carece de conexión con una sociedad árabe concreta del periodo premoderno. Así, las anécdotas reunidas por Ibn 'Āṣim — fuente de partida de este estudio- no resultan concluyentes para hablar de representaciones de las mujeres de las clases bajas de

10 Pellat, "Variations sur le thème de l'adab", pp. 26-27.

11 El único modo de salvar este obstáculo es cotejar cada uno de sus relatos con el corpus de obras previas, lo cual, además de ser una tarea ingente, tampoco nos proporciona ninguna garantía por diversos motivos: a) que un relato no se encuentre recogido por escrito en las obras del género que conocemos no quiere decir que no lo estuviera, puesto que hay muchas que no nos han llegado; b) no hay que olvidar las aportaciones procedentes de la tradición oral. Un determinado relato no incluido en otras obras del género pudo llegar a un hombre de letras desde un lugar del mundo árabe-islámico distinto a aquel desde donde escribía gracias a la oralidad. época nazarí, pues en su mayoría proceden -en último término - de obras orientales de siglos anteriores, algunas de las cuales, por ejemplo, fueron compuestas en plena época de esplendor de la sociedad abasí, momento dorado también de la literatura árabe clásica y, en lo que nos atañe, de la prosa de adab. Los Hadā'iq al-azāhir del granadino son herederos tardíos de una tradición del género que viene fundamentalmente de Oriente, ya que los ejemplares andalusíes de estas obras aportaron un porcentaje mínimo de noticias referidas al contexto andalusí o emanados de él. Tal es el caso de al- 'Iqd al-farìd de Ibn 'Abd Rabbihi (m. 328/940), referente indiscutible de Ibn 'Āșim.

Las mujeres que ocuparán estas páginas pertenecen, por tanto, a la tradición de la literatura de $a d a b$. En este sentido, y según lo explicado en los párrafos anteriores, entiendo que la tradición textual del género constituye el universo común a todos los autores que se citan - sea cual sea el contexto espacial y temporal desde el que escriben-y aporta a los relatos entresacados de unos ejemplares y otros la cohesión requerida para realizar un estudio de conjunto en torno a la temática señalada. A continuación, señalo los que entiendo como algunos ejemplos concluyentes en este sentido.

Tal y como apuntaba, es sabido que el grueso del contenido de los libros de $a d a b$ producidos por los hombres de letras en al-Andalus de corte enciclopédico, didáctico y humorístico - desde el primero a los más tardíos - procede de fuentes orientales del género. Ello se explica, en parte, debido a que al- Iqd al-farìd - principal referente para aquellos $u d a b \bar{a}^{\prime}$ andalusíes - bebe en buena medida de obras como 'Uyūn al-ahbūr de Ibn Qutayba, primera fuente de inspiración de Ibn 'Abd Rabbihi. Así, ese legado oriental se transmitió hasta obras postreras como Hadā'iq al-azāhir de Ibn 'Āșim, las cuales, por otro lado, tienen igualmente en cuenta otros ejemplares de la tradición del género por el motivo que explicaba unas líneas más arriba y que tiene que ver con la propia razón de ser del adīb. Basta cotejar los relatos que componen el repertorio del citado literato granadino, para comprobar que aquellos guardan paralelismos o son un calco de otros contenidos en obras de hombres de letras que escriben desde Oriente o el Magreb en distintos momentos antes que él, como el Kitāb al-buhalā' de al-Ğāhị (m. 255/868-869), Ğam al-ğawāhir y Zahr al-ādāb del qayrawān̄i Abū Isḥāq al-Ḥuṣrī (m. 413/1022), al-Bașā ir wa- 


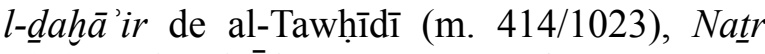
al-durr de al-Ābi (m. 421-422/1030-1031 o 432/1040), o Ahbār al-hamqà wa-l-mugaffalīn de Ibn al-Ğawzī (m. 597/1200), entre otras ${ }^{12}$. También es conocida la relación entre la Bahğat al-mağālis del cordobés Ibn 'Abd al-Barr (m. 463/1071) o al-Mustatraf del egipcio al-Ibšīhī (m. d. 850/1446) con respecto a al- 'Iqd al-farīd y otras obras orientales de la tradición del géne$\mathrm{ro}^{13}$; lo mismo que entre otros ejemplares de esta literatura de los que se hará uso en el presente artículo y cuyas conexiones no detallaremos para no dilatar demasiado este apartado introductorio, pues es posible advertirlas en adelante en algunas notas a pie de página en las que se señala la procedencia de los relatos empleados.

\section{La reclusión de las mujeres en las casas}

La sociedad patriarcal y patrilineal en el islam, que privilegió lo masculino en la vida social y la organización familiar, concibió los entornos urbanos y las vidas de quienes habitaban en ellos segregados por sexos ${ }^{14}$. En términos generales, desde el ideal teórico se concedió a los hombres el privilegio de poder disponer de la totalidad del espacio público libremente y sin ningún tipo de restricciones. La existencia de las mujeres, por su parte, debía desarrollarse entre las cuatro paredes de sus casas ${ }^{15}$. Apoyándose en una interpretación sesgada de las principales fuentes de la ley y el derecho islámicos, los juristas persiguieron con ahínco imponer dicho orden social, tratando que se proyectara en la vida diaria de las gentes. En la práctica, es absolutamente necesario atender a los factores indicados en páginas anteriores (estatus social y condición, origen étnico, confesión religiosa y medio urbano/rural) y al contexto espacio-temporal en el que transcurrió la existencia de las

\footnotetext{
12 V. López Bernal, El libro de los huertos, pp. 33-35 (introd. a Ibn 'Āṣim, Hadā' iq al-azāhir).

13 La segunda de las obras mencionadas también sigue el modelo de al- 'Iqd al-farīd en su estructura e, incluso, le hace un guiño en su título. V., respectivamente, Pinilla Melguizo, "Una obra andalusí de $a d a b "$, pp. 91-92, y Marzolph, "A Medieval Knowledge", pp. 411-412

$14 \mathrm{Al}$ respecto, v. Guichard, Al-Andalus. Estructura antropológica, p. 77.

15 Una postura extrema fue la del jurista egipcio de la escuela mālikí Ibn al-Hāăğğ (n. 737/1336), de época mameluca, quien en su Madhal al-šar 'al-šarīf restringía las salidas permitidas a las mujeres a lo largo de sus vidas a tres: para mudarse a la casa de su esposo, a la muerte de su padre y en el día de la suya propia. Ver Chapoutot-Remadi, "Femmes dans la ville mamlûke", p. 147.
}

mujeres para realizar un estudio de cuáles fueron las condiciones concretas de su vida cotidiana, algo que no se pretende hacer en este trabajo, en el que nos moveremos siempre en el terreno puramente literario, con el apoyo de la teorización que los intelectuales árabes-musulmanes realizaron al respecto.

En general, los hombres utilizaron su dominio del saber y la vida intelectual para contribuir a extender la idea de que las mujeres debían permanecer recluidas en sus casas ${ }^{16}$. La defensa de la división entre los espacios masculinos y el femenino (el hogar), que en la práctica afectó en mayor medida a las mujeres de la élite social, se repite en los tratados de derecho, los libros de hisba o la literatura ${ }^{17}$.

En este último caso, lo mismo obras en prosa que la poesía se convirtieron en potentes altavoces a través de los cuales se proclama la reclusión de las mujeres (en general) tras los muros de sus viviendas. En trabajos precedentes, ha sido citado el alfaquí, asceta y poeta granadino Abū Isḥāq al-Ilbīrī (m. 459/1067), quien hablaba en uno de sus versos de la necesidad de las mujeres de estar ocultas ${ }^{18}$. Esta necesidad se advierte, paradójicamente, desde la óptica masculina que - en ciertos casos como los que comentaré a continuación - considera a las primeras - en tanto depositarias del honor ( $i r d$ ) de los hombres de la familia - una posesión que preservar a salvo de miradas e intenciones ajenas, conteniendo al mismo tiempo la posibilidad de que ellas mismas se inclinaran hacia comportamientos considerados como no adecuados en toda mujer honesta. El punto de partida de esta interpretación se basa en el carácter sagrado que el islam otorgó a las mujeres, consideradas haram/hurma.

Como señalaba, los testimonios de distintos personajes masculinos que encontramos en la

16 Esta postura tiene una de sus fundamentaciones en Corán, "La coalición" (33:33), aleya que comienza con las palabras: "iQuedaos en vuestras casas!». V. Corán, p. 554; Fierro, "La mujer y el trabajo en el Corán y el Hadīt", p. 36.

17 Ver Chapoutot-Remadi, "Femmes dans la ville mamlûke", p. 146, nota 5, y Romero Morales, "Los tratados de hisba", pp. 147-160.

18 Ver Moral Molina, "La imagen de la mujer", vol. 2, p. 726. El verso pertenece a una casida zuhdiyya del dīwān del poeta en elogio de la pobreza y en él se alude a las mujeres de forma general. Se dice, textualmente (verso 4 de la citada casida): wa-l-niswa yabtagìna satran (trad. García Gómez: «y porque las mujeres necesitan estar ocultas»; trad. Pérès. «si no tuviera mujeres que exigen un abrigo»). V. Abū Isḥāq al-Ilbīrī, Un alfaquí español, pp. 107 y 109; Pérès, Esplendor de al-Andalus, p. 460. 
literatura de $a d a b$ nos transmiten, en ocasiones, la idea de las mujeres como una posesión más. El Compañero del Profeta, al-Mugīira b. Šu ba (m. 48-51/668-671) — de quien se dice haber contraído matrimonio entre trescientas y mil ocasiones y a quien se acusó de adulterio-, aseguraba haber «poseído» a las mujeres de tres formas (malaktu al-nisā' 'alà talāta tabaqāt). En otros relatos se las cosifica, comparándolas con unas sandalias o con una cama ${ }^{19}$.

En la literatura de $a d a b$, es frecuente que a las mujeres se las compare con las vergüenzas ('awra) que se han de ocultar de la vista de los demás, razón por la cual se incita a los hombres a mantenerlas dentro de sus casas ${ }^{20}$. En la enciclopédica Muhậ̣arāt al-udabā' de al-Rāgib al-Iṣfahānī (m. principios s. V/XI) - erudito religioso además de $a d \bar{l} b$ - leemos un epígrafe donde se reúnen varios testimonios en torno a la «incitación a velarlas y a prohibirles salir» ${ }^{21}$. Entre los argumentos que se proporcionan consta aquel del que me ocuparé a continuación, puesto en boca de distintas autoridades y en diferentes versiones en diversas fuentes de $a d a b$. Una de ellas es la también enciclopédica Bahğat al-mağălis de Ibn 'Abd al-Barr - famoso tradicionista, genealogista, especialista en Corán y hombre de letras andalusí que vivió entre los siglos IV/X-V-XI — donde se recoge la siguiente explicación al enclaustramiento femenino: «las mujeres fueron creadas de la debilidad ( $\left.d a^{\prime} f\right)$, así que poned remedio a su debilidad con el silencio y [ocultad] sus vergüenzas ('awrāt) en las casas ${ }^{22}$. Su informante era el famoso gra-

19 Ver, respectivamente, al-Ābī, Natr al-durr, t. 2, p. 80;

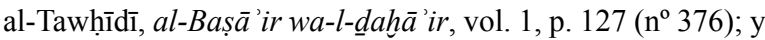
al-Ābī, Natr al-durr, t. 4, p. 163 y t. 3, p. 177; al-Tawhīì̄, alBașa ir wa-l-dahă ir, vol. 5, p. 37 (n 117). Las tres formas a las que se refería al-Mugīira son: con su potencia sexual durante su juventud, bromeando cuando era un mozo, y con dinero cuando se hizo mayor.

20 Al respecto, existe un hadiz de Muhammad que reza: «Las mujeres son vergüenzas: si salen, Satanás las observará atentamente». V. Al-Tirmid̄i al-Ǧàmi 'al-kabīr, vol. 2, p. 463 $\left(\mathrm{n}^{\circ} 1173\right)$ (véase la nota 1 a dicha edición para más referencias). Al-Tirmidī califica el hadiz como hasan, șaḥih y garīb. La raíz šarifa en la forma istašrafa, que se utiliza en la última parte del mismo, tiene el sentido preciso de 'elevarse' o 'erguirse sobre las piernas' (para contemplar algo). V. Biberstein Kazimirski, Dictionnaire Arabe-Français, t. 1, p. 1219.

${ }^{21}$ Al-Rāg̀ib al-Iṣfahānī, Muḥậarāt al-udabā', vol. 3, p. 216.

${ }^{22}$ V. Ibn 'Abd al-Barr, Bahğat al-mağālis, vol. 3 (segunda parte), p. 32. En Muhāạdarāt al-udabā', el informante es Sa 'īd b. Salmān. El término da 'f ('debilidad') suele emplearse en relación a las facultades intelectuales. En este caso, se utiliza como sinónimo de 'ayy, según se puede comprobar en los mático y filólogo de la escuela de Kufa Ta lab (m. 291/904). Este tomaba tal sentencia de otro ilustre filólogo de la misma escuela, Ibn al-A 'rābī (m. ca. 231/846) quien, en último término, remitía a la tradición como autoridad ( $q \bar{a} l \bar{u}$, 'dijeron'), en lo que todo apunta tratarse de un hadiz. En la misma línea se pronunciaba uno de los califas rāšsidūn, 'Umar b. al-Hattạāb (g. 13/63423/644), célebre por su recta conducta moral y su sabiduría, al que se le atribuyen multitud de sentencias misóginas en los libros de $a d a b^{23}$, como la siguiente:

Las mujeres son [partes] pudendas ('awra), así que ocultad vuestras vergüenzas en las casas y poned remedio a su debilidad [para expresarse] con el silencio ${ }^{24}$.

Otra versión de la misma sentencia que contribuyeron a propagar los libros de $a d a b$ reza así:

Uno dijo: -Dios creó a la mujer de dificultad para expresarse ('ayy) y vergüenzas ( 'awra): remediad la primera con el silencio y ocultad las vergüenzas en las casas ${ }^{25}$.

Los libros de $a d a b$, especialmente los de aspiración enciclopédica, incluyen entre los variados temas que abordan capítulos más o menos extensos dedicados a las mujeres y a sus cualidades, casi siempre en relación al matrimonio y a la vida conyugal (en la que tiene un especial protagonismo la sexualidad), con directrices hacia los hombres para que puedan conocerlas a fondo y proceder de la manera entendida como correcta en sus relaciones con ellas. En el $a d a b$ oriental, al-Ābī aconsejaba en Natr al-durr tres

siguientes relatos traídos a colación en el cuerpo del artículo. La cita se encuentra dentro del capítulo en torno a las mujeres y el matrimonio, concretamente en unos de sus epígrafes finales, titulado bāb ğāmi ' dikr al-nisā' wa-tazwīğ al-akfă' ('compendio de lo mencionado [sobre] las mujeres y el matrimonio de las parejas'), en el que se recopilan opiniones al respecto citadas bajo autoridades diversas. Entre ellas, abunda la del Profeta Muhammad, algunos de sus Compañeros y otros respetables personajes del islam, como varios de los califas rāšidūn y personajes sabios como Akțam b. Șayfī (m. 8/630).

23 En los Hadā'iq al-azāhir, 'Umar acaba dando la razón a una mujer que le replica por inducir a los hombres a no pagar un precio alto por las dotes de las mujeres. Finalmente, el califa asume que se ha equivocado y concede la razón a ella con esta rotunda afirmación: « ¿Una mujer que ha acertado y un hombre que se ha equivocado!». V. Ibn 'Āșim, Hadā'iq al-azāhir, p. 64, trad. López Bernal, El libro de los huertos, p. 79 ( $\left.\mathrm{n}^{\circ} 84\right)$.

24 Ibn Qutayba, 'Uyūn al-ahbār, t. 4, p. 78.

25 Al-Ābī, Natrr al-durr, t. 4, p. 203; al-Rāgeib al-Iṣfahānī, Muhạạarāt al-udabä', vol. 3, p. 216. 
cosas para convivir y tratar con las mujeres. $\mathrm{Su}$ primera anotación era: «hacedles quedarse en las casas» (alzamūhunna al-buyūt $)^{26}$. Dentro de la literatura del género en al-Andalus, el libro del segundo coral (al-marğāna al-țāniya) de al- 'Iqd al-farìd - primera de las obras de adab andalusíes - versa sobre las mujeres y sus atributos (fi l-nisā wa-șifätihinna). Entre sus distintos epígrafes distinguimos uno centrado en exponer - mediante anécdotas varias, como es propio del género - las cualidades comunes a todas las mujeres y los rasgos que definen su carácter (sifāt al-nisā' wa-ahlāquhunna). En él, leemos un relato donde un beduino enumera una serie de cualidades y virtudes deseables en la mujer que se entiende como esposa ideal, y lo hace, como es habitual, desde una perspectiva androcéntrica y considerando únicamente los deseos de los hombres. Junto a la sinceridad, la paciencia, la mesura en sus actos (en concreto, a la hora de reír), la obediencia a su marido o su fertilidad y capacidad para tener muchos hijos - cualidades, por otra parte, que dibujan el modelo de mujer que se perfila en las obras del género- se destaca también el quedarse en su casa como actitud digna de alabanza ${ }^{27}$.

Además de ocultarlas en las casas y silenciarlas, desde esta literatura se prescribe a los hombres que se les escondan los secretos y se las mantenga alejadas de las conversaciones. $\mathrm{La}$ falta de discreción es, de hecho, otro de los defectos que continuamente se atribuyen a las mujeres en las noticias que se pueden leer en estas fuentes. El silencio a la hora de mantener a buen recaudo los secretos - especialmente de su marido - es una virtud que se espera de la esposa ideal que se traza en capítulos — generalmente en torno al matrimonio - cuyo destinatario eran hombres y con los que se pretendía guiar a estos tanto en la búsqueda de la mejor mujer para contraer nupcias como en su proceder con ella en el transcurso del matrimonio ${ }^{28}$.

\footnotetext{
$26 \quad$ Al-Ābī, Natr al-durr, t. 4, p. 211.

27 Ibn 'Abd Rabbihi, Kitāb al-'Iqd al-farìd, vol. 6, p. 107. Relato traducido en El-Eryan, Hany, "Las mujeres y el matrimonio", p. 317. Otra versión se encuentra en al-Tawhīdī, al-Bașa ${ }^{\prime}$ ir wa-l-dahă ir, vol. 8, pp. 193-194 (nº 716).

28 En estos capítulos, las noticias que ilustran al público masculino proceden también de autoridades masculinas, salvo algunas excepciones, con lo que las mujeres son mayoritariamente objetos pasivos, sobre los que se habla, pero a los que raramente se concede voz. Una de esas excepciones es un relato que consta en varios de estos libros, en el que una madre proporciona una serie de consejos a su hija antes del matrimonio, buscando la satisfacción de su futuro esposo. Guardar sus secretos es
}

La sociedad patriarcal y patrilineal quiso que buena parte del universo de las mujeres en el mundo árabe premoderno y en las ciudades se redujera a sus hogares. Las mujeres de elevada posición social se sometieron al confinamiento impuesto en mayor medida que aquellas de clase media y baja. Los relatos extraídos de obras de $a d a b$ que vamos a comentar dibujan un panorama que confirma lo que sabemos por otro tipo de fuentes: más allá del teórico orden social, en el día a día la libertad de movimientos de aquellas últimas no estuvo tan limitada como para considerar que vivieron confinadas en sus hogares. Las mujeres (libres y esclavas) de las clases bajas tuvieron un contacto permanente con el exterior y cierta vida social. Salieron al espacio público, considerado eminentemente masculino. En la literatura de este género, las calles, las casas de vecinas u otras mujeres y otros escenarios urbanos son, de hecho, los decorados que acogen las escenas en las que las encontramos relacionándose con otros individuos, mujeres y hombres, como se verá.

Adentrándonos de lleno en el espacio eminentemente urbano relacionado con ella, la prosa de $a d a b$ nos presenta a mujeres que tienen contacto con el mundo exterior desde sus propias casas. Numerosos relatos nos cuentan cómo, en ausencia de sus maridos, otros hombres las observan, les lanzan señas o entablan conversaciones con ellas a través de los patios, las azoteas y las escasas ventanas que asomaban al exterior, reducidas en número y tamaño y adornadas con tupidas celosías o ajimeces. En los Hadā 'iq al-azāhir se nos cuenta la historia de un almuédano que, desde lo alto de su alminar y valiéndose de las privilegiadas vistas del corazón de las viviendas que la altura le brindaba, divisó en su casa a una mujer y se enamoró de ella. Mal parado salió, pues no fue correspondido por ella, que se quejó a su marido y entre los dos urdieron un plan para ahuyentar para siempre al incómodo pretendiente. En el relato posterior, en cambio, una mujer establece una relación con un almuédano que la pretendía desde el alminar y le permite acceder a su casa cuando su esposo no se encuentra en

una de sus recomendaciones. La desposada era Umm Iyās, hija de un personaje noble de la Ğāgiliyya, 'Awf b. Muhallim al-Šaybānī, que iba a convertirse en esposa del rey de Kinda, 'Amr b. Hiğr. V. Ibn 'Abd Rabbihi, Kitāo al- 'Iqd al-farìd, vol. 6, p. 83 y El-Eryan, Hany, "Las mujeres y el matrimonio", pp. 320-321 (específicamente p. 321); al-Ibšīhī, al-Mustatraf, vol. 2, p. 294, trad. Rat, al-Mostatraf, vol. 2, p. 595. 
ella ${ }^{29}$. La obra de Ibn 'Āṣim guarda también el siguiente testimonio:

Un hombre llegó a Bugía y exclamó: -¡Cuántos perros hay en esta ciudad! Entonces una mujer sacó la cabeza por una ventana $(t \bar{a} q)$ y dijo: $-i \mathrm{La}$ mayor parte de ellos son forasteros! ${ }^{30}$.

Las ventanas y los patios conectaron a las mujeres con la vida fuera de sus casas y fueron uno de los canales para establecer relaciones con los hombres. De nuevo Ibn 'Āṣim relata una anécdota en la que un hombre mira hacia una ventana alta ( $t \bar{a} q$ 'a $l i y y a)$ y encuentra en ella a una mujer hermosa limpiándose los dientes, con la que empieza a conversar y que finalmente le permite ir a verla. Por su parte, en el Kitāb al-adkiyā' de Ibn al-Ğawzī (m. 597/1200) -reputado jurista hanbali, historiador, tradicionista, predicador y hombre de letras, natural de Bagdad - se cuenta lo sucedido a un hombre que se solía parar debajo del ventanillo (rawšan) de una mujer, quien detestaba su presencia y planea una artimaña para deshacerse de él ${ }^{31}$. La mayoría de relatos que sitúan a las mujeres desprovistas de identidad que relacionamos con las clases bajas desde dentro de las viviendas en conexión con individuos (hombres) del exterior tiene como telón de fondo el amor, como muestra el sucinto muestrario que se acaba de aportar.

\section{La vida matrimonial}

Como se ha mencionado al inicio de este trabajo, la mayoría de las mujeres que desfilan por los huertos de los Hadā'iq al-azāhir pertenecen al pueblo llano. De niñas a ancianas, estas fé-

29 Ver, respectivamente, Ibn 'Āṣim, Hadā 'iq al-azāhir, p. 140, trad. López Bernal, El libro de los huertos, pp. 181-182 $\left(n^{\circ} 455\right.$ y no $\left.^{\circ} 456\right)$.

30 Ver, respectivamente, Ibn 'Āṣim, Hadā'iq al-azāhir, pp. 140 y 54, trad. López Bernal, El libro de los huertos, pp. $181-182\left(\mathrm{n}^{\mathrm{o}} 455\right.$ y n $\left.^{\mathrm{o}} 456\right)$ y p. $66\left(\mathrm{n}^{\circ} 35\right)$. La mencionada podría tratarse de una ventana en forma de arco. V. Biberstein Kazimirski, Dictionnaire Arabe-Français, t. 2, p. 122; Dozy, Supplément aux dictionnaires arabes, t. 2, p. 70.

${ }_{31}$ Ibn 'Āṣim, Hadā' iq al-azāhir, p. 61, trad. López Bernal, El libro de los huertos, p. 75 (n $\left.{ }^{\circ} 70\right)$ e Ibn al-Ğawzī, Kitāb al-adkiyà ', p. 256, respectivamente. El vocablo rawšan también puede traducirse como 'ojo de buey'. V. Corriente y Ferrando, Diccionario avanzado árabe, p. 434. Dozy lo vuelca al francés como 'balcon', mientras que para Kazmirski se trata de una 'claraboya' o 'ventana'. Cf., Dozy, Supplément aux dictionnaires arabes, t. 1, p. 532; Biberstein Kazimirski, Dictionnaire Arabe-Français, t. 1, p. 867. Ibn Manz̄ūr, Lisān al- 'arab, vol. 3, p. 1652 aclara que rawšan es sinónimo de kuwwa/kawwa ('ventanillo', 'ojo de buey' o 'tragaluz'). minas aparecen representadas en las funciones asignadas por la sociedad en la que viven, orientadas al cuidado de los hijos y la casa, la procreación y la satisfacción sexual de los hombres (son esposas, madres, hijas, etc.); también desempeñando algunos oficios, en general - pero no exclusivamente-, ejercidos por las mujeres en las sociedades medievales (lavandera, vendedora de agua, casamentera, alcahueta, hechicera, prostituta o nodriza).

La mayoría de las veces, las mujeres de las clases bajas que aparecen en la obra de Ibn 'Āṣim lo hacen desempeñando el papel de esposas. Las escenas de pareja suelen localizarse - aunque no se mencione explícitamentedentro de la vivienda y, en su inmensa mayoría, están relacionadas con la vida sexual y las relaciones sexuales. Otras veces encontramos a las mujeres realizando tareas domésticas, casi siempre cocinando ${ }^{32}$.

Las anécdotas que nos han transmitido los libros de $a d a b$ contradicen - en parte y con matices - los mensajes de sumisión sexual de las mujeres respecto a los hombres que también recogen en sus páginas, como el que lanzaba 'Alī b. Abī Țālib - cuarto de los califas rāšidūn (g. 35/656-40/661)_, a quien se atribuye la frase: «la mujer es como las sandalias: el hombre se las pone cuando quiere, no cuando ellas quieren $\rangle^{33}$. Por el contrario, en varios relatos de la obra de Ibn 'Āṣim hallamos que - en principio- las mujeres llevan la iniciativa y tienen poder de decisión de tener sexo con sus maridos. Refería el granadino:

Un hombre llevó a su casa zanahorias y le dijo a su esposa: -Si las haces cocinadas, servirán para la vista, y si nos las comemos crudas, el pene se fortalecerá. Y ella exclamó: -iSe ha roto la olla! ${ }^{34}$.

Sin embargo, relatos como el anterior también tratan de transmitir una imagen de las mujeres como seres concupiscentes y de enfatizar su inusitado gusto por el sexo, al que no pueden resistirse, cualidad que conforma el retrato de ellas que queda reflejado en estas fuentes literarias. En línea con esa pintura, el egipcio al-

32 Ibn 'Āṣim, Hadā 'iq al-azāhir, pp. 108, 160 y 225, trad. López Bernal, El libro de los huertos, p. 144 (n 326), p. 207 $\left(n^{\circ} 568\right)$ y p. $286\left(n^{\circ} 797\right)$, respectivamente.

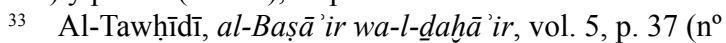
117). Ver también al-Ābī, Natr al-durr,t. 4, p. 163.

34 Ibn 'Āṣim, Hadā'iq al-azāhir, p. 160 (otro ejemplo en p. 163), trad. López Bernal, El libro de los huertos, p. 207 ( ${ }^{\circ}$ $568)$ y p. $212\left(n^{\circ} 593\right)$, respectivamente. 
Nuwayrī (m. 733/1333) aseguraba en Nihāyat $a l$-arab -magna enciclopedia de $a d a b$ de época mameluca - que Dios había creado el deseo en diez porciones y nueve de ellas estaban en las mujeres ${ }^{35}$. No obstante, la lascivia dentro del matrimonio se valora como una cualidad moral propia del modelo de esposa que el hombre ha de procurar según instruyen estos libros: «Dijo 'Alī, ¡Dios esté satisfecho de él!: La mejor de las mujeres es la casta ('afifa) y la lasciva ( $m u \dot{g}$ talima) para con su esposo» ${ }^{36}$.

Todo ello no quita el que, también en estas obras, se trate constantemente a las mujeres como meros objetos sexuales, en los que reside el honor de los hombres, carentes de palabra en unos relatos en los que tampoco tienen un papel activo como personajes ${ }^{37}$.

En los ejemplares de este género, la sexualidad de las mujeres es una de las temáticas centrales del humor que se hace sobre ellas y del hecho por ellas mismas. Recordemos que la gran protagonista de las anécdotas que componen los libros de $a d a b$ que se vienen citando es aquella mujer desprovista de identidad que relacionamos con las clases bajas, si bien el potencial público al que iban dirigidas dichas anécdotas formaba parte de las élites político-intelectuales. La otra gran temática en la que aparecen las mujeres de las clases más humildes es el matrimonio y la vida matrimonial, estrechamente ligada a la primera. Ambas revelan la perpetuación en la tradición del género de un modelo y un antimodelo de mujer tras los cuales se esconde una percepción e ideología patriarcal $\mathrm{y}$, muchas veces, misógina.

35 Al-Nuwayrī, Nihāyat al-arab, vol. 1, p. 273. Otro de los muchos relatos en clave de humor que pone el foco en la lascivia de las mujeres y que guardan estas fuentes se puede leer en al-Tawhīì̄i, al-Bașâ'ir wa-l-dahă 'ir, vol. 2, p. 100 (n 294): una mujer pasa junto a un viejo almuédano, al que halla jugueteando con su pene. En las palabras que le dirige recae todo el peso de la anécdota, cuya gracia reside en la desvergüenza y la lujuria que la mujer demuestra a la vez. Otros ejemplos

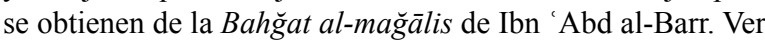
Lachiri, "La vida cotidiana", p. 109.

36 También cabría traducir los términos empleados como 'continente' e 'incontinente', respectivamente. La cita se repite en varias obras del género. Ver al-Rāgiib al-Ișfahānī, Muhạậarāt al-udabà', vol. 3, p. 202 y al-Zamahšarī, Rabī al-abrār , vol. 5 , p. $255\left(n^{\circ} 123\right)$ (en ambos casos el relato se trae a colación dentro del capítulo enfocado en el matrimonio).

37 Ver varios ejemplos en este sentido en al-Rāgib al-Ișfahānī, Muhâậarāt al-udabā', vol. 3, p. 239. En uno de los relatos, el marido sorprende a su esposa y al amante de ella copulando y, tras presenciar el final del acto, le invita a que contemple él mismo lo propio.
En relación con la vida matrimonial y el sexo, las temáticas más repetidas son el repudio, la infidelidad (de mujeres a hombres y viceversa) y la insatisfacción sexual de las primeras con sus maridos, la cual las lleva a presentar sus quejas ante el cadí, como se mencionará más adelante.

Las mujeres vivieron expuestas al peligro de ser repudiadas por sus esposos. Una de las injusticias que padecían era la posibilidad que otorgaba la $\check{s}^{-} \operatorname{rr}^{\prime} a$ a sus maridos de repudiarlas de una sola vez por tres veces. Las alusiones a dicha práctica en las anécdotas de la prosa de $a d a b$ son frecuentes. En la obra que centra nuestra atención en este trabajo se advierten dos ejem$\operatorname{plos}^{38}$. En ambos, el triple repudio de la propia esposa aparece en juramentos por parte de un personaje masculino. En ninguno de los casos se pone en evidencia tal proceder respaldado por la ley, llegándose incluso a frivolizar sobre dicho asunto. En una de las anécdotas citadas, se cuenta que un grupo de hombres es sorprendido en el desierto por un viento tan fuerte que temen morir, aunque finalmente salvan sus vidas. En agradecimiento a Dios, cada cual libera a un esclavo o a una esclava, salvo uno de ellos, que suplica: «- ¡Dios mío, yo no tengo ni esclava ni esclavo, pero repudiaré a mi mujer tres veces por darte gusto!». La gracia de la anécdota se aloja precisamente en la exclamación final, que reduce a las mujeres - como la propia práctica - a la pura insignificancia.

Una de las fórmulas de juramento más usadas por parte de los hombres en las anécdotas de estos libros y que hacía de las mujeres un objeto de usar y tirar, es jurar por el repudio de su mujer e -incluso - de la ajena. Se juraba por cosas tan banales como aquello por lo que lo hizo el hombre de la siguiente anécdota extraída de la obra de Ibn 'Āṣim:

Un hombre juró por el repudio de su mujer que alHağğāğ estaba en el Infierno. Y preguntó a al-Ḥasan al-Bașrī, que dijo: - ¡No te preocupes, $i b n$ ah̆ pues si al-Hağğāğ no está en el Infierno, no te perjudicará que estés con tu mujer en adulterio! ${ }^{39}$.

38 Ibn 'Āṣim, Hadā'iq al-azāhir, pp. 239 y 392-393, trad. López Bernal, El libro de los huertos, p. $302\left(\mathrm{n}^{\circ}\right.$ 867) y p. $449\left(n^{\circ} 1271\right)$.

39 Ibn 'Āṣim, Hadā 'iq al-azāhir, p. 72, trad. López Bernal, El libro de los huertos, p. 92 ( $\left.\mathrm{n}^{\circ} 121\right)$. El primero de los personajes citados fue predicador de Basora en época omeya (m. 110/728), célebre por su intachable conducta religiosa y moral y por sus sermones. Ver Ritter, "Al-Hasan al-Bașrī”. El temido gobernador omeya del Iraq, al-Hağğāăg es personaje recurrente en las anécdotas de los libros de $a d a b$. Esta en con- 
A veces, la explicación que se da al repudio de una mujer por parte de su esposo tiene que ver con cualidades o atributos físicos, como el hecho de que no fuera bella o de que tuviera una vulva amplia ${ }^{40}$. En este último sentido, en los Hadā 'iq al-azāhir leemos la siguiente anécdota:

$\mathrm{Y}$ preguntaron a una mujer que fue repudiada muchas veces: $-i$ Qué te pasa que eres repudiada siempre? Y contestó: - iLes gusta el estrecho! ¡Dios les haga pasar estrecheces! ${ }^{41}$.

A la inversa, las mujeres que protagonizan estos relatos van a solicitar su divorcio debido, entre otras razones que también se mencionan más adelante, a la impotencia sexual de sus esposos.

\section{La vida social y los espacios urbanos donde transcurren las vidas cotidianas de las mujeres}

Frente al empeño de los juristas por limitar las actividades de las mujeres al ámbito cerrado y de lo doméstico, en los libros de $a d a b$ de distintas épocas y lugares se nos presenta a aquellas libres de las clases bajas manteniendo encuentros con otros hombres más allá de sus parientes en las calles y en otros escenarios fuera del hogar, y una vida social que se desarrolla, en parte, en dichos escenarios exteriores.

La lectura y estudio de otra suerte de fuentes de diversa naturaleza puso sobre la mesa que la división ideal del espacio urbano a la que se

creto se lee también en otro ejemplar andalusí del género, Ibn 'Abd Rabbihi, Kitāb al- 'Iqd al-farìd, vol. 5, pp. p. 49, quien a su vez la tomó de Ibn Qutayba, 'Uyūn al-ahbār, t. 2, p. 245.

40 En la prosa de $a d a b$, los motivos más frecuentes que llevan a los esposos a repudiar a sus mujeres son: su insatisfacción sexual respecto a su esposa, un sentimiento de intensa ira hacia ella motivada por su comportamiento general o puntual, o su deseo de casarse con otra mujer más joven. Tenemos multitud de ejemplos en el dilatado corpus del $a d a b$. Ver los casos que cita Hämeen-Anttila, "Some Notes on Women", p. 135 a propósito de Ahbār al-nisā", atribuida al teólogo hanbali Ibn Qayyim al-Ǧawziyya (m. 751/1350).

${ }^{41}$ Ibn 'Āṣim, Hadā'iq al-azāhir, p. 67, trad. López Bernal, El libro de los huertos, p. 85 ( $\mathrm{n}^{\circ}$ 98). Otra anécdota similar se lee en p. 162, trad. López Bernal, El libro de los huertos, p. $211\left(n^{\circ} 588\right)$. Se alude a la creencia de que una vagina estrecha proporcionaría al hombre un mayor placer durante el coito, hecho por el cual dicha característica fue tan apreciada. Así lo demuestran las distintas insinuaciones en ese sentido que encontramos a lo largo de la obra. En los tratados árabes de erotología y sexualidad se prescribieron alimentos y remedios a las mujeres para que su vagina se estrechara. Ver, por ej., al-Šayzārī, al-Ị̇̂ăh fì asrār al-nikāhh, segunda parte, capítulo 9 (primera parte), trad. Lucena Romero, La sexualidad árabe, pp. 253-254. viene haciendo referencia fue transgredida -0 simplemente no fue tal - en las sociedades árabe-islámicas a lo largo de la Edad Media, ya en Oriente, en el Magreb o en al-Andalus. El continuo interés por evitar y prohibir que las mujeres salieran a las calles en los tratados de derecho y de hisba sugiere querer atajar una práctica contraria entre la mayoría de la sociedad. Los $\mathrm{Ha}$ dā'iq al-azāhir de Ibn 'Āṣim es una de las muchas obras de $a d a b$ que nos presenta a mujeres - sin más apreciaciones, como se ha destacado al inicio y es tónica general en estos relatos-en escenas que trascienden los muros de sus casas, acompañadas de sus maridos o en solitario. En presencia de estos, la situación que más se repite es la de los cónyuges que acuden ante el cadí para resolver un litigio o disputa entre ambos ${ }^{42}$.

Como Chapoutot-Remadi expone en lo tocante a la sociedad mameluca, los tratados jurídicos concedieron a las mujeres la posibilidad de salir de sus viviendas por razones concretas y previa autorización de sus maridos ${ }^{43}$. No es el caso de aquellas que en las anécdotas de la prosa de $a d a b$ acuden solas ante el juez para dar quejas de sus esposos. Las más frecuentes son el impago de la manutención (nafaqa) — su derecho y deber del marido- o su insatisfacción sexual, ocasionada por diversos motivos, como el tamaño pequeño de sus penes o el modo reprobable en que mantenían relaciones sexuales con ellas ${ }^{44}$. Las quejas que comento se perfilan

42 Ibn 'Āṣim, Hadā 'iq al-azāhir, pp. 105, 166 y 219, trad. López Bernal, El libro de los huertos, p. 140 (n 309), p. 216 $\left(n^{\circ} 613\right)$ y p. $278\left(n^{\circ} 764\right)$. En el relato $n^{\circ} 613$, quien tiene la iniciativa es la esposa y ella es quien cita a su marido ante el juez.

43 Chapoutot-Remadi, "Femmes dans la ville mamlûke", pp. $147-148$.

${ }^{44}$ Acerca de una y otra cuestión ver Ibn 'Āṣim, Hadā' iq al-azāhir, pp. 160 y 161, trad. López Bernal, El libro de los huertos, pp. 208-209 (nº 573 y no 576); al-Rāgìib al-Ișfahān̄i, Muhāạdarāt al-udabä', vol. 3, pp. 267-268, donde una mujer se queja al cadí de que su marido la penetraba por el trasero. Este acto, entendido como liwāt o 'sodomía', se refiere a la penetración anal por parte de un hombre a otro individuo, ya sea una mujer o un hombre. En torno a este asunto y su carácter lícito o no en caso de darse entre un hombre y una mujer existe una amplísima literatura. Las distintas posturas parten de la aleya coránica «Vuestras mujeres son campo labrado para vosotros. ¡Venid, pues, a vuestro campo como queráis, haciendo preceder algo para vosotros mismos!» (Corán, "La vaca", 2:223, pp. 44$45)$ y de una serie de hadices. Sobre la posición que adoptaron las distintas escuelas jurídicas del islam sunní y chií ver El Rouayheb, Before Homosexuality, pp. 118-128 y 137-138. En la literatura de $a d a b$ y la de tipo erótico abundan las anécdotas que hablan de esta forma de mantener sexo con las mujeres. En Nuzhat al-albāb de al-Tîfāšì hay todo un capítulo reservado a ello, ilustrado con anécdotas reunidas en un epígrafe final 
en los relatos de la literatura de $a d a b$ como las razones principales que llevan a las mujeres a solicitar el divorcio. En relación con el primer asunto mencionado contaba Ibn 'Āṣim:

Una mujer pidió ayuda contra su marido a 'Abbād b. Manșūr y aseguró que no le pagaba la manutención (nafaqa). 'Abbād le dijo a Ru'ba b. al'Ağğăğ: -¡Dirime el litigio entre ellos dos! Y este dijo:

¡Repúdiala si no eres buen pagador de la nafaqa (munfiq),

pues el hombre no es sino pagador o 'repudiador '(mutalliq/mutliq) $!^{45}$.

Prácticamente contemporáneo del granadino fue el egipcio al-Ibšīhī quien, desde el Egipto mameluco del s. IX/XV, también incluyó en al-Mustatraf relatos en los que mujeres de las clases bajas comparecen ante el cadi ${ }^{46}$. Por traer otro ejemplo a colación, en una de las anécdotas que componen Ahbār al-hamqà de Ibn al-Ğawzì - ejemplar de tendencia puramente humorística - una mujer acude ante el juez para reclamar que su marido la ha repudiado y presenta como prueba el testimonio de un vecino. La gracia del relato reside en las palabras finales del testigo, quien asegura haber escuchado pronunciar el triple repudio, si bien no tiene claro si ha sido

del mismo. Ver al-Tīfǎšī, Nuzhat al-albāb, pp. 221-230, trad. Gutiérrez de Terán, Esparcimiento de corazones, pp. 200-208.

45 Ibn 'Āṣim, Hadā'iq al-azāhir, p. 118, trad. López Bernal, El libro de los huertos, p. 158 (n ${ }^{\circ}$ 371). Otros ejemplos en Hämeen-Anttila. "Some Notes on Women", p. 135. Los personajes mencionados son: Abū Salama 'Abbād b. Manșūr al-Nāğ̄ (m. 152/769-770), quien ejerció como cadí de Basora durante cinco años; y el poeta Abū Ğaḥhāaf/Abū Muḥammad Ru'ba b. al-'Ağğāğ al-Tamīmī (m. 145/762), quien vivió a caballo entre la época omeya y principios de la abasí. Ver, respectivamente, al-Dahabī, Siyar a 'ām al-nubalä', vol. 7, pp. 105-106 (n. $\left.{ }^{\circ} 45\right)$; Pellat, “Al- Adjdjadj” [en línea]. Al final de la anécdota se hace referencia al papel del hombre en el seno del matrimonio como administrador o garante de la nafaqa. Este derecho de la esposa finalizaba una vez disuelto el matrimonio, ya fuera por repudio, como se insinúa en el relato, o tras el fallecimiento del marido.

46 Al-Ibšīhī, al-Mustatraf, vol. 1, pp. 152-153, trad. Rat, al-Mostatraf, vol. 1, pp. 313-314. La referencia remite a dos relatos que aparecen en el capítulo de esta enciclopédica obra destinado a hablar de la justicia y los cadíes. En uno de ellos, una mujer saca a relucir la necedad de un juez, al que ataca y colma de improperios a partir de la pregunta que aquel le formula - de una manera un tanto confusa - en relación a los testigos. En la segunda anécdota, al-Ša ' bī (m. 103/721-110/728) juzga a favor de una mujer hermosa y el poeta Hudayl al-Ašğa ' $\overline{1}$ compone cuatro versos que habrían de correr a posteriori entre la gente de Kufa, en los que explica el dictamen favorable de este famoso y reputado juez como consecuencia de haber sido seducido por la belleza de la mujer. la esposa quien ha repudiado a su marido o a la inversa ${ }^{47}$. Es evidente que aquello que se cuestiona en este relato no es la citada práctica, sino la inteligencia del personaje.

Un tema reiterativo en esta literatura de tintes humorísticos que se da en las escenas que se desarrollan ante un juez es el de la mujer que este $u$ otro personaje presente creen oprimida (en ocasiones porque entra ante ellos llorando) y a quien, mediante el recurso a la historia coránica de José o al descubrirse el rostro, se le acusa de ser la opresora ${ }^{48}$. En los primeros casos, se pone en duda la bondad y el testimonio de las mujeres, a las que se asocia con la malicia y se le atribuyen toda clase de engaños y artimañas (al-kayd y al-makd $)^{49}$; y en el segundo, se hace una burla de ellas por su fealdad, como en el relato que traduzco a continuación:

Un hombre y su mujer se citaron ante un cadí. Ella estaba velada. El cadí falló a su favor y el hombre se dio cuenta y dijo: -Eh, cadí, ¿has dudado de que ella es mi esposa? ¡Pues ordénale descubrirse el rostro! Eso le pareció bien al cadí, que le dijo:-¡Descúbrete el rostro! Y cuando la mujer se descubrió el rostro, la vio fea y exclamó: - ¡Dios os guarde! ¡Llega una de vosotras, en mi opinión oprimida, y cuando se ha descubierto, ha descubierto un rostro opresor! ${ }^{50}$.

47 Ibn al-Ğawzī, Ahbār al-ḥamqà, pp. 141-142.

48 Ibn 'Āṣim, Hadā' iq al-azāhir, p. 76, trad. López Bernal, El libro de los huertos, p. 98 ( $\left.\mathrm{n}^{\circ} 142\right)$. Otra versión se lee en Ibn al-Ğawzī, Kitāb al-ad dkiyā', p. 75.

49 «Buscad refugio en Dios contra las maldades de las mujeres», aconsejaba a los musulmanes el segundo de los califas rāšsidūn, 'Umar b. al-Hatțâb. Todo ello responde al retrato como servidoras de Iblīs y/o Šaytān que se hace de las mujeres en los libros de $a d a b$, especialmente, aunque no de forma exclusiva, en aquellos de tendencia enciclopédica, en los capítulos que se ocupan de ellas. Esta asociación es común a otras literaturas y tradiciones literarias medievales. Un hadiz de Muhammad citado con bastante frecuencia en la prosa de $a d a b$ y pronunciado por uno de sus Compañeros, 'Abd Allāh b. Mas'ūd, es el que reza: «Las mujeres son las trampas/la trampa de al-Šaytānn» (al-nisā' habā' il/habālat al-Šayțān). Ver, respectivamente, al-Ibšīhī, al-Mustatraf, vol. 2, p. 304, trad. Rat, al-Mostatraf, vol. 2, pp. 618-619; y al-Ābī, Natr al-durr, t. 1, p. 173 y t. 2, p. 69; Ibn 'Abd Rabbihi, Kitāb al- 'Iqd al-farīd, vol. 3, pp. 89 y 95 , vol. 4, p. 130 y vol. 6 , p. 126; al-Ibšīhī, al-Mustatraf, vol. 2, p. 303, trad. Rat, al-Mostatraf, vol. 2, p. 616; al-Rāgìib al-Ișfahānī, Muhậ̣arāt al-udabà', vol. 3, pp. 217-218; al-Tawhīì̄, al-Baṣā ir wa-l-dahă ir, vol. 7, p. 11.

so Ibn 'Āṣim, Hadā'iq al-azāhir, p. 219, trad. López Bernal, El libro de los huertos, p. 278 ( $\mathrm{n}^{\circ}$ 764). En los Hadā'iq al-azāhir también se cuentan relatos en los que mujeres se mofan de sus esposos por su aspecto físico. V. Ibn 'Āṣim, Hadā iq al-azāhir, p. 49, trad. López Bernal, El libro de los huertos, p. $58\left(\mathrm{n}^{\mathrm{o}} 11\right)$. 
En sentido inverso a lo que sucede en esta anécdota, en uno de los relatos extraídos de al-Mustatraf referenciados anteriormente se comprueba cómo el aspecto físico de estas mujeres condiciona la percepción que se tiene de ellas $^{51}$. En este tipo de anécdotas humorísticas, a ellas ni siquiera se les concede la posibilidad de expresarse. No es necesario, pues el foco está puesto inequívoca y únicamente en su físico.

El gobernador o el propio califa son otras autoridades ante las que las mujeres de las que me estoy ocupando se presentan en las anécdotas - en días de audiencia pública - para expresar sus quejas o darles a conocer alguna injusticia o agravio que habían sufrido (en el denominado mağlis al-mazālim). En la obra de Ibn 'Āṣim encontramos varios ejemplos en este sentido. En uno de ellos, una mujer acude ante el califa abasí Al-Ma' mūn (g. 197/813-218/833) para reclamar una finca de su posesión que le habían arrebatado; en otro, es una madre la que intenta salvar a su hijo de que le corten las manos por haber cometido un robo ${ }^{52}$. Escenas similares se repiten con muchísima frecuencia en otros libros del género. En algunas de ellas, las mujeres elevan su descontento con sus maridos ante el representante del poder judicial o político. Como en al- 'Iqd al-farìd, donde Ibn 'Abd Rabbihi recoge un relato en el que una mujer lleva una disputa con su marido ante Sālim b. Qutayba, personaje que ejercía entonces como gobernador de Jurasán, y le expresa su rechazo hacia aquel «por [las] cualidades que hay en él» ${ }^{53}$.

De otra parte, los libros de $a d a b$ nos muestran a las mujeres - dentro de un matrimonioejerciendo un cierto control sobre la educación de sus hijos y recurriendo a los maestros para reconducir comportamientos o conductas inapropiadas de aquellos. A través de al-Ğāhiiz, Ibn 'Āṣim relataba cómo una mujer se presentó ante un maestro con su hijo quejándose de su falta de obediencia y pidiendo al instructor que lo asustara para que su conducta hacia ella cambiara. Obviamente, se trata de una situación cómica, cuyo desarrollo completo es el que sigue:

Al-Ğāḥiz dijo: Una mujer trajo a su hijo ante un maestro que tenía una barba larga y unos ojos bri-

\footnotetext{
${ }^{51}$ Véase el segundo de los relatos a los que remite la nota 46.

52 Ibn 'Āṣim, Hadā'iq al-azāhir, pp. 396-397 y 80, trad. López Bernal, El libro de los huertos, pp. 454-455 (n 1281) y p. $104\left(n^{\circ} 160\right)$.

${ }^{53}$ Ibn 'Abd Rabbihi, Kitāb al- 'Iqd al-farìd, vol. 6, p. 112.
}

llantes y que era feo. Y le dijo: -Este niño está decidido a no obedecerme y quiero que lo atemorices. Entonces el maestro cogió su barba, se la metió en la boca, hinchó las comisuras de la boca, miró con ojos dilatados, agitó la cabeza y dio un grito. La mujer soltó una ventosidad del susto y exclamó:-¡Te he dicho 'asusta al niño', y no a mí! Y el maestro le dijo: - ¡ Vete, tonta, pues si la plaga desciende, morirán el bueno y el malo! ${ }^{54}$

En otros casos, por motivos que no se especifican, la mujer resulta inaccesible para el maestro y ambos se comunican a través del hijo de ella:

Un maestro quiso casarse con una mujer cuyo hijo estudiaba en su escuela y que era inaccesible para él. Así que ordenó hacerle llevar a su hijo y le pegó y le pegó. Y le dijo: -Dile a tu madre: ' $¡ L a$ verga del maestro es grande!'. Y cuando el niño regresó a su madre, le dijo: $-i E l$ maestro me ha pegado y me ha dicho esto y lo otro! Entonces ella le envió este mensaje: ¡Trae los testigos inmediatamente y nos casamos! $!^{55}$.

La abundancia de noticias que nos presentan a mujeres que acuden en solitario ante los maestros de sus hijos pueden estar revelando lo frecuente que debieron ser estas situaciones. En otra enciclopedia de bellas letras, al-Bașā ir wal-daha ${ }^{\prime} i r$, al-Tawhīīi (m. 414/1023) — adīb y filósofo árabe oriental - refiere una anécdota en la que una mujer hermosa llega a un maestro a quejarse de su hijo y el primero reprende al niño por tratar mal a su madre, haciéndole ver que debería hacer cualquier cosa por tenerla conten$\mathrm{ta}^{56}$. En estos casos, la belleza de las mujeres es la cualidad que las hace merecedoras de un trato excelente por parte de los personajes masculinos. De nuevo, el aspecto físico marca la suerte $\mathrm{y}$ el trato que reciben los personajes femeninos en los relatos de la prosa de $a d a b$.

A los lugares de las urbes por los que transitaron las mujeres de las capas bajas de la sociedad se les denomina frecuentemente «espacios frontera». Son, fundamentalmente, mercados, baños públicos, mezquitas, hornos y espacios periurbanos como cementerios, santuarios, huertos,

54 Ibn 'Āṣim, Hadā 'iq al-azāhir, pp. 259-260, trad. López Bernal, El libro de los huertos, p. 325 (n ${ }^{\circ}$ 956). El maestro, que califica de tonta a la mujer, no es el más autorizado para hacerlo, pues ya se sabe la imagen que la literatura de $a d a b$ transmite de estos profesionales. No es esta una excepción, pues sus palabras finales terminan por condenarlo a él también.

55 Ibn 'Āṣim, Hadā'iq al-azāhir, p. 164, trad. López Bernal, El libro de los huertos, p. 213 ( $\left.{ }^{\circ} 600\right)$.

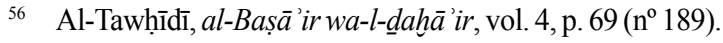


jardines y ríos. En casi todos los libros de $a d a b$ podemos encontrar anécdotas en las que mujeres de las clases bajas marchan por las zonas comerciales y conversan con los vendedores, todos ellos hombres, aunque hubo vendedoras y mujeres que se dedicaron a diferentes actividades comerciales ${ }^{57}$. Salir a hacer las compras se muestra como una actividad habitual y casi ritual de estas mujeres. Todos los textos recabados nos las presentan solas. En Ahbār al-hamqà de Ibn al-Ğawzī, leemos una anécdota en tono jocoso en la que una mujer llega a un hombre que vendía granadas por los mercados y que, tras tratarla de estúpida, demuestra con su respuesta ser él mismo más necio ${ }^{58}$.

En estas anécdotas que persiguen esbozar sonrisas, a las mujeres se las representa en muchas ocasiones en uno de los papeles que mayor frecuencia asumen en la literatura del $a d a b$ al-fukāha, como es la de burladora con grandes dosis de ingenio, deslenguada las más de las veces. Una muestra es el siguiente relato extraído de Natr al-durr de al-Ābī:

Una mujer llegó a un pregonero (munādin) en el mercado y dijo: - ¡Coge este morral y vocifera en él! Y señaló hacia su coño. Él respondió: -Ahora mismo estoy ocupado, pero cuélgalo en esta estaquilla para que derrame [el semen]. Y señaló hacia su pene ${ }^{59}$.

Uno de los vendedores que más clientela femenina debía tener era el perfumero, a cuya tienda llegan dos mujeres en sendos relatos de los Hadā'iq al-azāhir. En uno de ellos, como decíamos, la mujer pone la nota de humor con una réplica directa y procaz a la intencionada exclamación de su interlocutor masculino:

57 Un ejemplo es el oficio de sarrāqa, que Ibn Hazm menciona en Tawq al-hamāma y que García Gómez traduce como 'vendedora ambulante'. El cordobés también aludía a las dallāla-s o corredoras de objetos. Ver Ibn Hazm, Tawq al-hamāma, p. 35, trad. García Gómez, El collar de la paloma, p. 145; Marín, Mujeres en al-Andalus, pp. 288-291.

58 Ibn al-Ğawzī, Ahbār al-ḥamqà, p. 159.

59 Al-Ābì, Natr al-durr, t. 4, p. 249. El munādin o pregonero en el zoco tenía como misión hacer públicas las ordenanzas del almotacén (muhtasib). Por otro lado, según informaba el sevillano Ibn 'Abdūn (s. VI/XII), cada gremio debía tener un pregonero que recordara a sus miembros la obligación de realizar la oración. Ver Ibn 'Abdūn, Sevilla a comienzos del siglo $X I I$, pp. 87-88. El mercado es, por excelencia, un lugar donde las voces de los comerciantes pregonando sus mercancías se entremezclan, por lo que el término munādin en la anécdota también podría interpretarse como 'uno que daba voces', refiriéndose a uno de esos vendedores.
Una mujer llegó a un perfumero a comprarle algo. A él le gustó ella, así que comenzó a hacerle señas y a decirle: -¡El auténtico (al-hurr), oh hurra! Y ella le respondió: $-i$ El coño (hir $[r])$ de tu madre! ${ }^{60}$.

Los relatos que leemos en estas fuentes muestran a unos personajes femeninos que se valen por sí mismos para desprenderse de compañías que no les agradan, o que dejan sin palabras gracias a su ingenio y sus respuestas desvergonzadas a hombres que las importunan y lanzan insinuaciones de todo tipo, que atacan su apariencia física o buscan el trato carnal con ellas. Un ejemplo es el siguiente que aparece, de nuevo, en la obra de Ibn 'Āṣim:

Un hombre se encontró con una mujer hermosa y empezó a abordarla y a pedirle que se descubriera su rostro para él. Ella le dijo:-¡Oye tú, vuélvete! Él se negó y la importunó. Entonces la mujer entró en un portalón y se descubrió el rostro, cuya belleza compartía la luna llena. Y le espetó: -iContempla aquello hacia lo que tu verga está levantada y con lo que copula otro que no eres tú! ${ }^{11}$.

Volviendo a los mercados y zonas comerciales, en otras fuentes de $a d a b$ la variedad de comerciantes a cuyos locales acuden las mujeres de las clases bajas a realizar sus compras es bastante amplia ${ }^{62}$. Desde el zapatero y los comerciantes de tejidos, hasta el joyero, al que comprarían las mujeres de clase media y mayor poder adquisitivo. Una de las anécdotas que narra el encuentro entre una mujer y un joyero es la que reproducimos a continuación, relatada bajo la autoridad de al-Ğāhị y de la que se han hecho eco varios hombres de letras posteriores:

${ }^{60}$ Ibn 'Āșim, Hadà iq al-azāhir, p. 161, trad. López Bernal, El libro de los huertos, p. 209 ( ${ }^{\circ}$ 578). En este contexto, hurra se refiere a una mujer virgen, casta y virtuosa. La frase posee un doble sentido, pues la mujer entiende $a l-h i r(r)$ ('el coño'), en lugar de al-hurr ('el auténtico', referido al perfume que le está ofreciendo), y cree que el perfumero le está solicitando mantener relaciones sexuales. El otro relato al que aludíamos puede leerse en p. 138, trad. p. $179\left(\mathrm{n}^{\circ} 440\right)$.

${ }_{61}$ Ibn 'Āṣim, Hadā iq al-azāhir, p. 168, trad. López Bernal, El libro de los huertos, p. 219 ( ${ }^{\circ}$ 628); Ibn 'Abd Rabbihi, Kitāb al- 'Iqd al-farìd, vol. 6, p. 448.

62 Las esclavas que desfilan en los relatos de los Hadāiq al-azāhir son, fundamentalmente, cantoras o del entorno de la corte, y nunca las encontramos en la obra realizando compras en los mercados. En muchas ocasiones son simplemente personajes pasivos. Ver, a modo de ejemplos, Ibn 'Āṣim, Hadā' iq al-azāhir, pp. 88, 393-394, 394 y 421-422, trad. López Bernal, El libro de los huertos, p. 115 ( $\left.\mathrm{n}^{\circ} 196\right)$, p. 450 ( $\left.\mathrm{n}^{\circ} 1274\right)$, pp. $451-452\left(n^{\circ} 1276\right)$ y pp. 489-491 (n 1344$)$. 
Dijo al-Ğāhị: Nadie me ha avergonzado nunca salvo una mujer que fue conmigo a un joyero y le dijo: -Haz uno como este. Y me quedé desconcertado. Luego pregunté al joyero y me dijo: -Esta mujer quiso que le hiciera la imagen de Satanás. Y le dije: -No sé cómo dibujarlo. Entonces me vino contigo para que lo dibujara con tu imagen ${ }^{63}$.

Por su parte, en Natr al-durr de al-Ābī tenemos esta vez a una mujer que lleva a reparar un caldero a un avispado calderero o latonero quien, pese a las protestas de su clienta, se sale con la suya y no repara correctamente el utensilio que le había entregado. En la misma obra, encontramos en otro relato de temática obscena a una mujer tratando con un domador o amaestrador de bestias ${ }^{64}$.

Frente a estos relatos que se viene de citar, encontramos otros en los cuales es el marido quien se encarga de hacer la compra para que su esposa prepare la comida:

Un hombre compró tres arreldes de carne y le dijo a su mujer: -¡Cocínala! Y se fue a su trabajo. La mujer cocinó la carne y se la comió. Y cuando llegó su marido dijo: - ¡Trae lo que has cocinado! Y ella contestó: - ¡Se lo ha comido el gato! Entonces el hombre cogió el gato y lo pesó, y he aquí que pesaba tres arreldes. Y le dijo a su esposa:-Si este es el peso del gato, ¿dónde está entonces la carne?, o, si este es el peso de la carne, ¿dónde está entonces el gato? ${ }^{65}$.

63 Al-Ibšīhī, al-Mustatraf, vol. 1, p. 387, trad. Rat, al-Mostațaf, vol. 1, pp. 816-817; Ibn Ḥamdūn, al-Tadkira al-hamdūniyya, vol. 9, p. 348 (nº 683); al-Zamahšarī, Rabī al-abrār, vol. 2, p. $191\left(\mathrm{n}^{\circ} 51\right)$

${ }^{64}$ Al-Ābi, Natr al-durr, t. 7, p. 322 y t. 2, p. 204; Ibn 'Abd Rabbihi, Kitāb al- 'Iqd al-farìd, vol. 4, p. 51.

${ }^{65}$ Ver Ibn 'Āṣim, Hadā' iq al-azāhir, pp. 108, 160 y 225, trad. López Bernal, El libro de los huertos, p. 144 (n 326). El relato fue recogido por primera vez en Oriente en el s. IX, formulado por al-Ğāhiz en su mínima expresión, lo cual es indicador de su transmisión previa. Al respecto, ver López Bernal, "Los cuentos de Ibn 'Āșim, p. 352 (n' 14, ATU 1373). Otro ejemplo, citado en páginas precedentes, se observa en la misma obra $\mathrm{p}$. 160, trad. López Bernal, El libro de los huertos, p. 207 (n 568) También desde el periodo nazarí, la Tuhfat al-mugtarib de Ahmad al-Qaštālì (m. d. 670/1271-1272), obra de tipo hagiográfico en torno a la figura del šayh sufí procedente de Ohanes (Yuhānis), Abū Marwān al-Yuhānisīi (m. 667/1268-1269), contiene dos relatos ambientados en el contexto rural de la Alpujarra almeriense, en los cuales se repite la misma situación que recrean las dos anécdotas recogidas por Ibn 'Āṣim. En uno de ellos, un pariente del šayh Abū Marwān pregunta a su hermana: «¿quieres que salga y te compre conejo en la tienda?»; en el segundo, se cuenta que el šayh «compraba carne en el zoco, que era llevada a su esposa; ella recibía (la carne), la cocinaba y la preparaba [...]». Ver al-Qaštālī, Ahmad b. Ibrāhīm, Tuhfat al-muğtarib: trad. Boloix Gallardo, Prodigios del maestro sufi, pp. 267 y 287.
En sus paseos por las calles, los testimonios de la literatura de $a d a b$ que venimos presentando no nos representan expresamente a las mujeres veladas, por considerarlo algo obvio. Solo cuando el velo es clave en el desarrollo de la escena que se está narrando se hace mención expresa a él. Las mujeres que salían fuera de casa lo portaban y las situaciones que nos refieren las fuentes de $a d a b$ no son, en este sentido, excepcionales $^{66}$. La salida autorizada de las mujeres de sus viviendas estuvo sometida en los tratados de derecho al denominado adab al-hurūğ, normas de comportamiento y directrices que afectaban a su forma de vestir e incluso caminar por las calles. Consistían, básicamente, en vestir de forma recatada para pasar desapercibidas y cubriendo lo que se consideraba 'awra (aquellas partes del cuerpo que no debían mostrarse), lo cual incluía llevar el velo, caminar pegadas a los muros para dejar el paso libre a los hombres y bajando las miradas ${ }^{67}$. Tras su estudio de diversas fuentes mamelucas, Chapoutot-Remadi aseguraba que estas directrices no fueron prácticamente observadas en el Egipto mameluco del s. VIII/XIV ${ }^{68}$. En la Granada nazarí, Ibn 'Āṣim recogía el siguiente refrán popular: «Para cuando la cegajosa se ponga el velo, se habrá disuelto el mercado de los hilados»), que ya constaba en el repertorio de refranes andalusíes del vulgo reunido por al-Zağğālī (m. 694/1294) y en el que se alude a cómo la mujer debía ataviarse con el velo para salir al exterior ${ }^{69}$.

66 Más adelante traeremos a colación otros relatos en los que aparecen mujeres veladas que caminan por diferentes espacios de las ciudades.

67 Estas normas se fundamentan en Corán, "La luz" (24:31), p. 461: «Y di a las creyentes que bajen la vista con recato, que sean castas y no muestren más adorno que los que están a la vista, que cubran su escote con el chal y no exhiban sus adornos sino a sus maridos, a sus padres, a sus suegros». Para el cordobés Ibn Hazm, tanto las mujeres libres como las esclavas debían cubrirse con un himār (la misma prenda mencionada en la aleya coránica citada) el cuerpo, salvo las manos y el rostro; también las piernas y los pies. Ver Adang, "Women's Access to Public Space", p. 78. Sobre lo que distintos autores consideraban como 'awra en el cuerpo de las mujeres, ver pp. 77-80.

68 Chapoutot-Remadi, "Femmes dans la ville mamlûke", p. 148.

${ }^{69}$ Ibn 'Āṣim, Hadā'iq al-azāhir, p. 322 (refrán no 313), trad. López Bernal, El libro de los huertos, p. 391 (refrán n ${ }^{\circ}$ 314); Marugán Güémez, El refranero andalusí, p. 109 ( $\left.{ }^{\circ} 314\right)$; al-Zağğāalì, Amtāal al- 'awāmm fì l-Andalus, vol. 2, p. 128 (n 564), trad. Ould Mohamed Baba, Estudio dialectológico, p. 78 $\left(\mathrm{n}^{\mathrm{0}} 564\right)$. Poco se sabe de la vida de al-Zağğāāī. Aunque murió en Marraquech, la sección de su obra editada por Muhammad b. Šarīfa/Bencherifa en la que se encuentra este proverbio se refiere a al-Andalus, como se comenta en el cuerpo del artículo. 
Extramuros de las ciudades, los cementerios y santuarios fueron también espacios de afluencia femenina, pese a las reticencias por parte de algunos expertos en ley, quienes veían un peligro la mezcla en ellos con los hombres ${ }^{70}$. Hemos encontrado algún testimonio literario en distintas obras de $a d a b$ que sitúa la presencia femenina en estos lugares. En Ahbār al-hamqà se relata en clave de humor el encuentro entre dos mujeres, una de las cuales le dice a su compañera haber estado ese mismo día en la tumba de Ahmad:

Una mujer le dijo a otra: -Hoy caminé hacia la tumba de Aḥmad y se me metió en el pie un clavo. La otra le preguntó: - ¿La pantufla era nueva? -No-respondió. -Pues entonces da gracias a Dios-replicó ${ }^{71}$.

Otros espacios periurbanos como las orillas de los ríos eran lugar de reunión habitual de las mujeres que acudían a lavar la ropa ${ }^{72}$. Ibn 'Āṣim incluye entre las flores de sus huertos un relato que se repite en un buen número de libros del género y que tiene como protagonistas al renombrado poeta omeya al-Farazdaq (m. ca. 110/728 o 112/730) — conocido por sus mordaces sátiras - y a un grupo de mujeres que se encontraban en el río lavando y que consiguen que el primero se marche avergonzado gracias a la aguda réplica de una de ellas en esta situación:

Al-Farazdaq pasó junto a un río en el que había unas mujeres lavando sus ropas. Dijo: Su mula soltó una ventosidad y las mujeres se rieron de él. Y al-Farazdaq les dijo: -¿Por qué os reís? ¡Por Dios! ¡Nunca me ha llevado una hembra que no haya hecho lo que ha hecho ella! Y una mujer le contestó: $-¿$ Es que acaso viste cómo eran las ven-

70 Desde la Sevilla del s. VI/XII, Ibn 'Abdūn solicitaba el esfuerzo del almotacén y del cadí para impedir que los vendedores se instalaran en los cementerios pues, en sus palabras, «lo que hacen es contemplar los rostros descubiertos de las mujeres enlutadas». También para impedir que los muchachos aprovecharan los días festivos para acudir a los cementerios a observar a las mujeres. Pedía, asimismo, vigilancia para evitar que los cementerios se convirtieran en lupanares. Igualmente parece que se instalaban en los cementerios sevillanos cuentacuentos y personajes que leían las manos. Ver Ibn 'Abdūn, Sevilla a comienzos del siglo XII, pp. 96-97.

71 Ibn al-Ğawzī, Ahbār al-ḥamqà, p. 158.

72 Traemos de nuevo a colación el testimonio de Ibn 'Abdūn, quien instaba a impedir que las mujeres lavaran sus ropas cerca de donde los aguadores iban a recoger agua del Guadalquivir o de los embarcaderos; también que se sentaran en las riberas de los ríos en los mismos lugares que los hombres, especialmente en verano. Ver Ibn 'Abdūn, Sevilla a comienzos del siglo XII, pp. 109 y 143. tosidades de la que te llevó en su vientre nueve meses? Entonces él se avergonzó y se marchó ${ }^{73}$.

Otros lugares con importante presencia femenina en el contexto urbano fueron las mezquitas, consideradas por los juristas, al igual que el resto de «espacios frontera», lugares proclives a desatar la promiscuidad en hombres y mujeres. De ahí que muchos hombres de ley en distintos momentos y lugares del mundo árabe-islámico aconsejaran a las segundas —aun sin encontrarse en ninguna de las situaciones establecidas que les impedían acudir al espacio reservado para ellas en la mezquita - realizar sus oraciones en casa ${ }^{74}$. Al-Ibšihī, muerto dos décadas después de Ibn 'Āṣim, contaba en su difundida enciclopedia de $a d a b$ un relato en el que informaba de lo siguiente a propósito del tercer esposo de una mujer noble como la mequí 'Ātika ${ }^{75}$ :

Después de él ['Umar b. al-Hattāb], se casó con al-Zubayr b. al-'Awwām, que era un hombre celoso. 'Âtika solía salir a la mezquita de costumbre junto a sus esposos, pero a al-Zubayr le afligía y no le gustaba prohibirle salir para rezar, debido al hadiz del Enviado de Dios, ¡Dios le bendiga y salve!: -Y no prohibáis a las siervas de Dios las mezquitas de $\operatorname{Dios}^{76}$.

En los Hadā'iq al-azāhir leemos algunos relatos que sugieren que en los ambientes rurales la separación entre hombres y mujeres a la hora del rezo no fue tan rígida, ya que muchas veces no se llevaba a cabo dentro de una mezquita. En estos textos se representa a unos y otras compartiendo un mismo espacio, aunque distribuidos por sexos. Contaba Ibn 'Āṣim:

73 Ibn 'Āṣim, Hadā'iq al-azāhir, pp. 50-51, trad. López Bernal, El libro de los huertos, p. 61 ( $\left.{ }^{\circ} 20\right)$. Se lee también, entre otras, en Ibn 'Abd Rabbihi, Kitāb al- 'Iqd al-farìd, vol. 4 , p. 52, con pequeñas variantes en su comienzo, que en nada afectan a lo esencial de la misma; y, en otra versión, en al-Ā bī, Natr al-durr, t. 2. p. 212 e Ibn Hạdūn, al-Tadkira al-ḥamdūniyya, vol. 7, p. 241.

74 Chapoutot-Remadi, "Femmes dans la ville mamlûke", pp. 153 y 157-158; López de la Plaza, Al-Andalus: mujeres, sociedad y religión, pp. 57-59.

75 Antes de contraer matrimonio con el personaje que se menciona en la anécdota, fueron esposos de 'Ātika 'Abd Allāh/ 'Abd al-Rahmmān, un hijo de Abū Bakr y 'Umar b. al-Hatțāb. Ver Fück, “'Ātika” [en línea]; al-Ibšīhī, al-Mustatraf, vol. 2, p. 296, trad. Rat, al-Mostatraf, vol. 2, pp. 600-602.

${ }_{76}$ Al-Ibšīhī, al-Mustatraf, vol. 2, pp. 296-297, trad. Rat, al-Mostatraf, vol. 2, p. 602. Como es bien sabido, al-Zubayr b. al-'Awwām fue uno de los más célebres Compañeros de Muhammad. 
Un hombre rezó con un grupo de beduinos en el mes de ramadán. Tras él había unas mujeres detrás de la fila de los hombres. Y comenzó a rezar y leyó: -«Casad a aquellos de vosotros que no estén casados». Y se le trabó la lengua y lo repitió varias veces. Y cuando se marcharon, una de las mujeres le dijo a sus hermanas: -iPor Dios, no ha dejado de ordenarles que se casen con nosotras, tanto que he temido que saltaran sobre nosotras! ${ }^{17}$.

En el relato inmediatamente anterior dentro de la misma obra, una beduina se detiene ante unos hombres que rezaban juntos e interrumpe su oración con una frase ocurrente ${ }^{78}$.

Otras anécdotas tienen como protagonistas a mujeres que se mueven sin la presencia de acompañantes masculinos por espacios más recónditos y solitarios de las urbes, donde estaban expuestas a más peligros, al mismo tiempo que a menos miradas. Precisamente en estos escenarios, como los callejones, se producen encuentros fortuitos con hombres desconocidos. Sirva como ejemplo el siguiente, narrado en las páginas de Natr al-durr, que pone su foco de atención en lo cómico de la situación:

Una mujer pasó por un callejón y se peyó. Y se dio la vuelta y he aquí un viejo detrás de ella. - ¡Ay de mí! —exclamó- ¿Cuánto tiempo estás detrás de mí? Respondió el viejo: -Desde que serviste el aperitivo $^{79}$.

Como ocurre habitualmente, la escena no se sitúa durante un momento concreto del día, pero la ausencia de mención expresa a la noche invita a pensar que estas escenas atemporales se desarrollarían a lo largo de la mañana o de la tarde o, en todo caso, antes de que oscureciera. Volviendo a al-Andalus, Ibn 'Āṣim toma del cordobés Ibn 'Abd Rabbihi — su principal referente cuando compone sus Hadá 'iq - un chistecillo en el que una mujer hermosa es abordada por la calle por un hombre y este le pide que le muestre su rostro. La mujer, que se encuentra velada, se defiende de él con su ingenio y sale airosa de una incómoda situación, imponiéndose humorísticamente hablando al hombre ${ }^{80}$.

77 Ibn 'Āṣim, Hadā'iq al-azāhir, p. 244, trad. López Bernal, El libro de los huertos, p. 308 (n $\mathrm{n}^{\circ}$ 893). El texto entrecomillado en la anécdota se corresponde con Corán, "La luz" (24:32), p. 462.

78 Ibn 'Āṣim, Hadā'iq al-azāhir, p. 243, trad. López Bernal, El libro de los huertos, p. 308 (n ${ }^{\circ}$ 892).

79 Al-Ābī, Natr al-durr, t. 6, 2, p. 557. Se advierte una errata en el texto de la edición, donde consta طَبَق الثتقل (tabaq al-taql), en lugar de طَبَق النقل (tabaq al-naql/nuql).

${ }^{80}$ Ibn 'Āṣim, Hadā'iq al-azāhir, p. 168, trad. López Bernal,
En los libros de $a d a b$, la vida social de las mujeres se desarrolla, en parte, en las calles, que son también lugar de encuentro con sus amigas $^{81}$. La literatura de $a d a b$ nos descubre relatos como el que sigue, extraído de Natr al-durr de al-Ābì, en el que dos mujeres pasean al atardecer el día del '̄̃d:

Uno dijo: Escuché a una mujer en la Puerta del Arco [Bāb al-Ṭāq] mientras le estaba diciendo a su amiga en la tarde del día del 'Īd:-¿Qué has visto, hermana mía, en este gentío? Respondió: -Hermana, he visto lo asombroso: he visto vergas que se extienden y úteros que están fatigados ${ }^{82}$.

Como los hombres, las mujeres alargaban hasta el atardecer, e incluso más allá de él, sus paseos durante las festividades, cuando las calles bullían de vida y de gente y las normas vigentes se relajaban. La anécdota anterior deja entrever - en un clima de mayor permisividad - la intensa actividad sexual de ellos y ellas en esas fechas señaladas, al tiempo que dibuja un panorama de promiscuidad y desenfreno sexual tras la abstinencia preceptiva del mes de Ramadán alejado del sentimiento religioso que debía acompañar la fiesta y que parece transgredir también los límites de las relaciones lícitas intra-matrimoniales.

Otra porción importante de la vida social de las mujeres transcurre en el interior de las casas de vecinas y amigas. Como apuntaba Nadia Lachiri en uno de sus trabajos, las mujeres visitaban a otras en sus casas en ocasiones especiales como, por ejemplo, para dar el pésame ${ }^{83}$, pero también para el rezo y, en definitiva, como parte de su vida social y del día a día. La sabiduría popular acuñó el refrán «si no te necesitara, no te visitaría, vecina», que recogía Ibn 'Āṣim en su colección de proverbios del pueblo en árabe dialectal granadino ${ }^{84}$. Los libros de $a d a b$ contienen relatos en los cuales se encuentra a las

El libro de los huertos, p. 219 (n 628); Ibn 'Abd Rabbihi, Kitāb al- 'Iqd al-farīd, vol. 6, p. 448. El relato puede leerse supra.

${ }_{81}$ El mercado de los hilados ( $s \bar{q} q$ al-gंazl), al que se aludía en el refrán popular recolectado por Ibn 'Āșim y citado con anterioridad, fue también un lugar ampliamente frecuentado por las mujeres y lugar de reunión para ellas. Ver Marín, Mujeres en al-Andalus, pp. 271 y 291.

${ }^{82}$ Al-Ābī, Natr al-durr, t. 4, p. 252. Se menciona la Bāb al-Ṭāq, puerta situada al este de la ciudad de Bagdad. Ver Yāqūt al-Hamawī, Mu'ğam al-buldān, vol. 1, p. 308.

83 Lachiri, "La vida cotidiana", p. 120

84 Ibn 'Āsim, Hadā'iq al-azāhir, p. 336 (nº 495), trad. López Bernal, El libro de los huertos, p. 400 (refrán no 497); Marugán Güémez, El refranero andalusí, p. 130 (refrán nº 497). 
mujeres recurriendo a sus vecinas para pedirles prestada cualquier cosa que necesitaban. En $A h$ bār al-ḥamqà, Ibn al-Ğawzī nos transmitió la siguiente anécdota, que arroja interesante información sobre esta y otras cuestiones del universo femenino:

\section{Una mujer llegó a casa de una vecina suya a pe- dirle prestado un $i z \bar{a} r$ para marcharse a un asunto y devolvérselo enseguida. Y la vecina le dijo: $-\mathrm{He}$ tejido de mi izār diez velos. Así que ten paciencia hasta que termine el hilado y se lo entregue al te- jedor y este lo acabe y yo te lo dé a ti. ¡Y no pases por donde haya un clavo, que es nuevo! ${ }^{85}$.}

La anécdota también proporciona noticias sobre las prendas que las mujeres vestían para

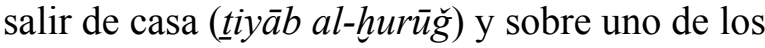
trabajos remunerados que llevaron a cabo, el hilado, actividad que prácticamente monopolizaron y que proporcionó a las viudas un medio para ganarse el sustento diario y, a las casadas y solteras, ingresos extra a los que aportaba por obligación el cabeza de familia ${ }^{86}$. En una de las flores de los Hadā iq al-azāhir, leemos la historia de un hombre que se había visto en la ruina y cuya familia vivía gracias al trabajo como hilandera de su esposa:

Había en el vecindario del cadí Abū 'Umar un hombre al que le apareció en su mano una gran fortuna después de una larga pobreza. Dijo: -Le pregunté por su asunto y dijo: «Heredé una gran fortuna y me apresuré a derrocharla, hasta que llevé el asunto al punto de vender los muebles de mi casa. No me quedó más remedio. Me quedé sin más sustento que el del hilar de la madre de mis hijos y deseé la muerte» ${ }^{87}$.

La situación que se narra en la historia es excepcional, pues el marido parece no ejercer ningún trabajo ni aportar ingresos a la economía familiar, incumpliendo así la obligación establecida en la ley islámica de mantener a su esposa e hijos.

Las mujeres de condición humilde trabajaron fuera de sus casas desempeñando diferentes ofi-

${ }_{85}$ Ibn al-Ǧawzī̄, Ahbār al-ḥamqà, p. 158. El izārr, referido a las mujeres, era un gran velo con el que estas se cubrían el cuerpo, salvo una pequeña parte de vestido y del velo del rostro. Ver Dozy, Dictionnaire détaillé des vêtements, pp. 24-38.

86 Ver Shatzmiller, Labour in the Medieval Islamic World, p. 351; Marín, Mujeres en al-Andalus, pp. 269-271.

87 Ibn 'Āṣim, Hadā'iq al-azāhir, p. 383, trad. López Bernal, El libro de los huertos, p. 440 (n 1258). Abū 'Umar fue cadí de Bagdad (m. 320/932), famoso por su inteligencia, su juicio y su rectitud. Ver al-Hațî̉ al-Bag̀dādī, Tārīh Madīnat al-Salām, vol. 4, pp. 635-639 (n. $\left.{ }^{\circ} 1798\right)$. cios en el ámbito urbano y el rural. En cuanto al trabajo de hilandera, era ejercido en las propias casas, pero implicaba un contacto de estas mujeres de las clases bajas con los hombres que conformaban la cadena de producción y venta de los productos textiles, a la vez que les permitía integrarse en ella ${ }^{88}$ : desde los proveedores de materias primas y los reparadores de ruecas - que acudían a las casas para la venta y reparación-, hasta los tejedores - que muchas veces actuaban de intermediarios, como muestra el relato extraído de $A$ hbbār al-hamqà citado con anterioridad - o los vendedores.

Asimismo, algunos de los oficios que desempeñaron las mujeres de condición modesta les exigían desplazarse a casa de otras. Era el caso de las peinadoras o peluqueras. Este oficio (māšița) fue ejercido por las mujeres árabes-musulmanas desde Oriente a al-Andalus. Es una de las ocupaciones a las que solían dedicarse las mujeres enumeradas por Ibn Hazm en el Tawq al-hamāma ${ }^{89}$. De entre las cuantiosas referencias que nos aportan los libros de $a d a b$, traemos a colación aquí la que nos proporciona al-Nuwayrī referida al Egipto mameluco. Este narra la historia de una peinadora famosa de El Cairo a quien una vieja reclama para que lleve a una mujer recién casada tejidos y adornos para engalanarse en su noche de bodas. A continuación, nos cuenta lo sucedido a la peinadora, que acaba asesinada cuando llega, de noche, a casa de la novia ${ }^{90}$. El relato nos brinda información relativa al trabajo de estas mujeres. Además de mencionar expresamente que la peinadora recibiría un salario («como de costumbre», se especifica), se nos muestra a esta mujer ejerciendo su oficio de noche, cuando de asistir a las recién casadas se trataba. El texto sugiere que le van a pagar una cantidad mayor de dinero por desplazarse a esas horas. Además, esta célebre peinadora cairota del relato debía haberse hecho con una buena fortuna, tanto como para permitirse contar con una ayudante, una muchacha ( $\check{g} \bar{a} r i-$ ya) que se ocupaba de transportar los tejidos y las alhajas.

Del mismo modo que las peinadoras, las comadronas o parteras (qābila/qawābil) prestaban sus servicios a otras mujeres en las casas de sus clientas, como se representa en este relato de Ahbār al-ḥamqà:

88 Marín, Mujeres en al-Andalus, p. 269.

89 Ibn Ḥazm, Tawq al-ḥamāma, p. 35, trad. García Gómez, El collar de la paloma, p. 145.

90 Al-Nuwayrī, Nihāyat al-arab, vol. 30, pp. 65-66. 
Dijo: -La esposa de Abū Hudayl fue repudiada y le dijeron a este:-Márchate detrás de la comadrona. Y se llegó a ella y dijo: -Ve a nuestra casa para que asistas en el parto a mi mujer y te apliques en que sea un muchacho y te deberé un dinar ${ }^{91}$.

Desde su dimensión literaria, los libros de $a d a b$ recogen abundante información sobre el trabajo doméstico de las mujeres y también sobre las actividades remuneradas que estas desempeñaron, reflejando, de igual modo, la posición mayoritaria de los hombres, que fue mirar con recelo el trabajo femenino en cualquiera de las formas que no fuera el meramente relacionado con el cuidado de los hijos y la casa, como correspondía a su concepción como pastora del hogar (rā'iya 'alà al-bayt $)^{92}$. No obstante, por la propia naturaleza y finalidad del $a d a b$, recomendaciones como las que citamos en la nota que precede a estas palabras y otras que se han ido trayendo a colación a lo largo de estas páginas, iban dirigidas expresamente a los hombres cultos que leían estas obras como guía para proceder con sus esposas y, por tanto, hemos de entenderlas aplicadas a mujeres de una clase social media-alta, en tanto que estos individuos eran parte de la élite política e intelectual.

\section{Conclusiones}

Los relatos que hemos podido recabar de la lectura de distintas obras de $a d a b$ en relación con la existencia cotidiana de las mujeres árabes-musulmanas del pueblo llano durante la época premoderna vienen a confirmar la información que - a partir de otra tipología de fuentes escritas y la arqueología - teníamos al respecto, y que la dilatadísima bibliografía publicada ha ayudado paulatinamente a interpretar y perfilar. No obstante, esta literatura aporta noticias de interés que ayudan a seguir trazando las distintas parcelas de su vida privada y pública y a tratar de construir un relato de cómo pudo

91 Ibn al-Ğawzī, Ahbār al-ḥamqà, p. 134. El personaje citado fue un teólogo mu 'tazilí, natural de Basora, que vivió entre finales del s. II/VIII y mitad del s. III/IX. Ver Mourad, "Abū 1-Hudhayl" [en línea].

92 Ver, por ejemplo, al-Rāàib al-Iṣfahānī, Muhạạdarāt al-u$d a b \bar{a}$, vol. 3, p. 216, donde se alude a la desgracia que puede ocasionar a las mujeres el hilar y dedicarse a una profesión, ilustrada por el verso y la noticia recogidos en dicho apartado, que lleva por título «el inducirles a su desgracia con el hilado y [el ejercicio] de una profesión» (al-ḥatt 'alà šifä ihinna bil-magzal wa-l-mihna). La visión de las mujeres como pastoras en el hogar se basa en los hadices. Ver Fierro, "La mujer y el trabajo en el Corán y el Ḥadīt”, p. 37. transcurrir su existencia diaria. En este sentido, los Hadā'iq al-azähir son, con creces, la fuente de $a d a b$ de época nazarí más rica en presencia femenina y, más concretamente, en mujeres que no pertenecieron a las clases elevadas de la sociedad árabe-islámica premoderna.

Los libros de $a d a b$ también pueden ser útiles para reconstruir parte del pensamiento sobre las mujeres por parte de las élites y, más concretamente, de la élite intelectual, que compone estas obras cultas y dirigidas a un público también cultivado. Muchas de ellas, por otra parte, parecen reflejar los comportamientos y prácticas sociales propios de las clases bajas y sus relatos trazan una representación literaria de cómo aquellas pudieron ser vistas por los hombres de su mismo estrato social (sus maridos, fundamentalmente, y otros individuos con los que tuvieron contacto en su existencia cotidiana).

Las anécdotas que hemos comentado coinciden con las noticias extraídas de otras fuentes en tanto que no muestran una separación tan rígida de espacios entre mujeres y hombres de las clases bajas como cabría esperar del discurso dominante e ideal. Por lo general, las fuentes tienden a transmitirnos este discurso dominante y menos los comportamientos de la vida cotidiana en relación con las mujeres. Los libros de $a d a b$ constituyen un pequeño resquicio, ya que abren una pequeña ventana - literaria, eso sí- desde la que indagar en estas cuestiones.

Las mujeres representadas en los relatos de la prosa de $a d a b$ establecieron relaciones personales fuera de sus casas y tuvieron contacto lo mismo con otras mujeres que con hombres que no eran sus familiares, a partir de que salían a comprar a los mercados, a lavar al río, o a prestar un servicio en casa a otras mujeres, durante el ejercicio de otros oficios, en sus visitas a los maestros de sus hijos o a otros lugares públicos. Los espacios exteriores son el contexto principal donde se producen estas relaciones que, del mismo modo, se establecen dentro o desde dentro de las viviendas. Las anécdotas muestran a las mujeres de una posición más baja en la pirámide social muy presentes en los lugares públicos del entorno urbano.

En cuanto al patrón de mujer sin mayores precisiones que con más frecuencia aparece en esta literatura, en contraposición a la mujer hermosa, fiel y sumisa - preferiblemente casada - aquella otra libertina, adúltera, infiel, deslenguada, mordaz, astuta, engañadora e incluso malvada es la que adquiere verdadero protagonismo a lo largo de los libros de $a d a b$, especialmente en 
las anécdotas de tintes cómicos. Esta es la mujer a un mismo tiempo burladora y burlada, que se muestra inteligente, perspicaz $y$, por encima de todo, ingeniosa. Su ingenio no es entendido y contemplado siempre en su vertiente negativa, ni las mujeres dibujadas en todas las ocasiones como astutas o maliciosas. El ingenio se aprecia también como una cualidad positiva en ellas $y$, unido a la desvergüenza, se erige en su principal valedor y en su herramienta de autoafirmación y libertad.

\section{Fuentes y bibliografía}

Al-Ābī, Abū Manșūr, Natrr al-durr, Muhammad 'Alī Qarna, Sayyida Ḥāmid 'Abd al-Āl, Muhammad Ibrāhīm 'Abd al-Raḥmān y Munīr Muḥammad alMadanī (eds.), El Cairo, Mațba at Dār al-Kutub wa-l-Watâ̄' iq al-Qawmiyya, 2010, 7 t. en 8 vols.

Abū Isḥāq al-Ilbīrī, Ibrāhīm, Un alfaquí español. Abū Ishāq de Elvira. Texto árabe de su Dīwān según el ms. Escur. 404, Emilio García Gómez (trad., introd., análisis, notas e índices), Madrid-Granada, CSIC, 1944.

Adang, Camilla, "Women's Access to Public Space According to al-Muhalla bi-l-Āthār", en Manuela Marín y Randi Deguilhem (eds), Writing the Feminine: Women in Arab Sources, London/New York, I.B. Tauris-The European Science Foundation, 2002, pp. 75-94.

Biberstein Kazimirski, Albin de, Dictionnaire ArabeFrançais contenant toutes les racines de la langue arabe, Paris, Maisonneuve, 1860, 2 t.

Chapoutot-Remadi, Mounira, "Femmes dans la ville mamlûke", Journal of the Economic and Social History of the Orient, 38, 2 (1995), pp. 145-164.

Corán, Julio Cortés (trad.), Barcelona, Herder, 1999.

Corriente, Federico y Ferrando, Ignacio, Diccionario avanzado árabe, $2^{\mathrm{a}}$ ed., Barcelona, Herder, 2005.

Al-Dahabī, Abū 'Abd Allāh Muhammad, Siyar a lām al-nubalā', Husayn al-Asad et al. (eds.), $11^{\mathrm{a}}$ ed., Beirut, Mu' assasat al-Risāla, 1996, 25 vols., vol. 7.

Dozy, Reinhart, Supplément aux dictionnaires arabes, $3^{a}$ ed., Leyde, E. J. Brill, 1881, 2 t.

Dozy, Reinhart, Dictionnaire détaillé des vêtements chez les arabes, Amsterdam, Jean Müller, 1845.

El-Eryan, Hany, "Las mujeres y el matrimonio en el Kitāb al- 'iqd al-farīd de Ibn 'Abd Rabbihi al-Andalusī', Sharq al-Andalus, 10-11 (1993-1994), pp. 313-323.

El Rouayheb, Khaled, Before Homosexuality in the ArabIslamic World, 1500-1800, Chicago, University of Chicago Press, 2005.

Fierro, M..$^{\mathrm{a}}$ Isabel, "La mujer y el trabajo en el Corán

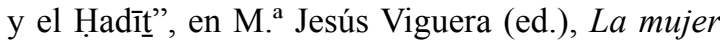
en Al-Andalus reflejos históricos de su actividad y categorías sociales, Madrid, Universidad Autónoma, 1989, pp. 35-51.

Fück, Johann W., “'Ātika”, en P. Bearman et al. (eds.), Encyclopaedia of Islam, Second Edition, [en línea], doi: http://dx.doi.org/10.1163/1573-3912_islam_ SIM 0847.

Ghersetti, Antonella, "La représentation des pique-assiette dans la littérature d'adab", Annales islamologiques, 42 (2008), pp. 213-230.

Guichard, Pierre, Al-Andalus. Estructura antropológica de una sociedad islámica en Occidente, Barcelona, Barral Editores, 1976.

Hämeen-Anttila, Jaakko, "Some Notes on Women in Classical Arabic Literary Tradition", Arabist: Budapest Studies in Arabic, 15-16 (1995), pp. 133-141.

Al-Hațīb al-Bag̀dādī, Abū Bakr Aḥmad b. 'Alī, Tārīh Madīnat al-Salām = Tārīh Bag̀dād, Baššār 'Awwād Ma rūf (ed.), Beirut, Dār al-Ġarb al-Islāmī, 2001, 17 vols., vol. 4.

Ibn 'Abd al-Barr, Abū 'Umar Yūsuf, Bahğat al-mağālis wa-uns al-muğālis, Muhammad Mursī al-Hūlì (ed.), $2^{\text {a }}$ ed., Beirut, Dār al-Kutub al- 'Ilmiyya, 1982, 3 vols., 2 partes, vol. 3.

Ibn 'Abd Rabbihi, Aḥmad, Kitäb al- 'Iqd al-farìd, Aḥmad Amīn, Aḥmad al-Zayn e Ibrāhīm al-Abyārī (eds.), El Cairo, Lağnat al-Tảlīf wa-1-Tarğama wa-l-Našr, 1949-1965, 7 vols.

Ibn 'Abdūn, Muḥammad b. Aḥmad, Sevilla a comienzos del siglo XII. El tratado de Ibn 'Abdūn, Emilio García Gómez y Évariste Lévi-Provençal (trads.), $2^{\mathrm{a}}$ ed., Sevilla, Servicio de Publicaciones del Ayuntamiento de Sevilla, 1981.

Ibn 'Āṣim, Abū Bakr, Hadā' 'iq al-azāhir, 'Afîf 'Abd alRaḥmān (ed.), Beirut, Dār al-Masīra, 1987: El libro de los huertos en flor (Hadā'iq al-azāhir). Cuentos, refranes y anécdotas de la Granada nazarí, Desirée López Bernal (trad., estudio y notas), Granada, Editorial Universidad de Granada, 2019.

Ibn al-Ğawzī, 'Abd al-Raḥmān b. 'Alī, Ahbār al-hamqà wa-l-mugaffalīn, al-Sayyid Zakariyā al-Șabbāg (ed.), El Cairo, Dār al-Faḍīla li-1-Našr wa-l-Tawzì’ wa-1Taṣdīr, 2007.

Ibn al-Ǧawzī, 'Abd al-Raḥmān b. 'Alī, Kitāab al-aḍkiyā', Beirut, Dār al-Kutub al-'Ilmiyya, 1985.

Ibn Ḥamdūn, Abū l-Ma'ālī Muhammad, al-Taḍkira al-ḥamdūniyya, Iḥsān 'Abbās y Bakr 'Abbās (eds.), Beirut, Dār Șādir, 1996, 10 vols., vol. 9.

Ibn Ḥazm, Abū Muḥammad 'Alī, Ṭawq al-hamāma fí l-ulfa wa-l-uläf, Ḥasan Kāmil al-Ṣayrafĩ (ed.) e Ibrāhīm al-Abyārī (introd.), El Cairo, al-Maktaba al-Tiğāriyya al-Kubrà, 1950: El collar de la paloma: tratado sobre el amor y los amantes, Emilio García Gómez (trad. e introd.), prólogo de José Ortega y Gasset, Madrid, Alianza, 1981. 
Ibn Manẓūr, Abū l-Faḍl Muhammad, Lisān al- 'arab, 'Abd Allāh 'Alī 1-Kabīr, Muḥammad Hasab Allāh, Hāšim Muhammad al-Šādilī y Sayyid Ramaḍān Aḥmad (eds.), El Cairo, Dār al-Ma ārif, 1981, 6 vols., vol. 3.

Ibn Qutayba, Abū Muhammad 'Abd Allāh, 'Uyūn alahbār, Muḥammad 'Abd al-Qādir Hāatim (ed.), El Cairo, Wizārat al-Taqāfa, 1963, 4 t., t. 4.

Ibn Simāk, Abū 1-Qāsim Muhammad, Kitāb al-zaharāt al-mantūura, Maḥmūd 'Alī Makkī (ed.), Revista del Instituto Egipcio de Estudios Islámicos de Madrid (Mağallat al-Ma 'had al-Miṣrī li-l-Dirāsāt alIslāmiyya fi Madrīd), 20 (1979-1980), pp. 5-76 y 21 (1981-1982), pp. 5-79.

Al-Ibšīhī, Abū l-Fath Muhammad, al-Mustațraf fì kulli fann al-mustaẓaf, Beirut, Manšūrāt Dār Maktabat al-Hayā, 1992, 2 vols.: Al-Mostatraf. Recueil des morceaux choisis çà et là dans toutes les branches de connaissances réputées attrayantes Gustave Rat (trad.), Paris/Toulon, Ernest Leroux/Th. Isnard \& B. Brun-Paul Tissot, 1899-1902, 2 vols.

Lachiri, Nadia, "La vida cotidiana de las mujeres en AlAndalus y su reflejo en las fuentes literarias", en Celia del Moral Molina (ed.), Árabes, judias y cristianas: mujeres en la Europa medieval, Granada, Universidad de Granada, 1993, pp. 103-121.

López Bernal, Desirée, “Los cuentos de Ibn 'Āṣim (m. 1426): precedentes en la península ibérica de relatos españoles y del folklore universal en el s. XV (continuación)", Bulletin of Hispanic Studies, 97, 4 (2020), pp. 349-365, [en línea], doi: https:// doi.org/10.3828/bhs.2020.20.

López de la Plaza, Gloria, Al-Andalus: mujeres, sociedad y religión, Málaga, Universidad de Málaga, 1992.

Malti-Douglas, Fedwa, Woman's Body, Woman's Word: Gender and Discourse in Arabo-Islamic Writing, Princeton, Princeton University Press, 1991.

Marín, Manuela, Mujeres en al-Andalus, Madrid, CSIC, 2000, Estudios onomástico-biográficos de al-Andalus, XI.

Marín, Manuela, "Las mujeres de las clases sociales superiores. Al-Andalus, desde la conquista hasta finales del Califato de Córdoba", en M. ' Jesús Viguera (ed.), La mujer en Al-Andalus reflejos históricos de su actividad y categorías sociales, Madrid, Universidad Autónoma, 1989, pp. 105-127.

Marugán Güémez, Marina, El refranero andalusí de Ibn 'Așim al-Garnāțī. Estudio lingüistico, transcripción, traducción y glosario, Madrid, Hiperión, 1994.

Marzolph, Ulrich, “A Medieval Knowledge in Modern Reading: A Fifteenth-Century Arabic Encyclopaedia of Omni Re Scibili", en Peter Binkley (ed.), PreModern Encyclopaedic Texts. Proceedings of the Second COMERS Congress, Groningen, 1-4 July 1996, Leiden-New York-Köln: Brill, 1997, pp. 407-419.
Moral, Celia del, "La imagen de la mujer a través de los poetas árabes andaluces (s. VIII-XV)", en Pilar Ballarín y Teresa Ortiz, (eds.), La Mujer en Andalucía. $1^{\circ}$ Encuentro Interdisciplinar de Estudios de la Mujer, Granada, Universidad de Granada, 1990, vol. 2, pp. 703-730.

Mourad, Suleiman A., "Abū 1-Hudhayl”, en Kate Fleet, Gudrun Krämer, Denis Matringe, John Nawas y Everett Rowson (eds.), Encyclopaedia of Islam, Three, [en línea], doi: http://dx.doi.org/10.1163/15733912_ei3_SIM_0289.

Al-Nuwayrī, Aḥmad b. 'Abd al-Wahhāb, Nihāyat al-arab fi funūn al-adab, Mufĩd Qumayḥa et al. (eds.), Beirut, Dār al-Kutub al- 'Ilmiyya, 2004, 33 vols.

Pellat, Charles, "Al-'Adjdjadj”, en P. Bearman et al. (eds.), Encyclopaedia of Islam, Second Edition, [en línea], doi: http://dx.doi.org/10.1163/1573-3912_ islam_SIM_0327.

Pellat, Charles, "Variations sur le thème de l'adab", en Charles Pellat, Études sur l'histoire socio-culturelle de l'Islam (VIIe-XVe siècle), London, Variorum Reprints, 1976, pp. 19-37.

Pérès, Henri, La poésie andalouse en arabe classique au $X I^{e}$ siècle. Ses aspects géneraux, se principaux thèmes et sa valeur documentaire, Paris, Librairie d'Amérique et d'Orient Adrien Maisonneuve, 1937: Esplendor de al-Andalus. La poesía andaluza en árabe clásico en el siglo XI. Sus aspectos generales, sus principales temas y su valor documental, Mercedes García-Arenal (trad.), Madrid, Hiperión, 1983.

Pinilla Melguizo, Rafael, "Una obra andalusí de $a d a b$ : la Bahŷat al-maŷālis de Ibn 'Abd al-Barr (s. XI JC)", Sharq al-Andalus, 6 (1989), pp. 83-101.

Al-Qaštālī, Aḥmad b. Ibrāhīm, Tuḥfat al-muġtarib: Prodigios del maestro sufí Abū Marwān al-Yuhānisis̄ de Almería. Estudio crítico y traducción de la Tuhfat al-mugtarib de Ahmad al-Qaštālī, Bárbara Boloix Gallardo (estudio crítico y trad.), Madrid, Mandala, 2010.

Al-Rāg̣ib al-Ișfahān̄̄, al-Ḥusayn b. Muhammad, Muhâạarāt al-udabā' wa-muḥāwarāt al-šu 'arā' wa-l-bulaġ $\bar{a}$, Beirut, Manšūrāt Maktabat al-Hayā, s. d., 4 vols., vol. 3 .

Ritter, Hellmut, “Al-Hasan al-Bașrī”, en P. Bearman et al. (eds.), Encyclopaedia of Islam, Second Edition, [en línea], doi: http://dx.doi.org/10.1163/1573-3912_ islam_COM_0273.

Romero Morales, Yasmina, "Los tratados de hisba como fuente para la Historia de las mujeres: presencia y ausencia en el espacio urbano andalusí”, Hesperia. Culturas del Mediterráneo, 9 (2008), pp. 147-160.

Sadan, Joseph, "Conflicting tendencies between higher and lower strata of humor", en Georges Tamer (ed.), Humour in der arabischen Kultur/Humour in Arabic 
Culture, Berlin and New York, Walter de Gruyter, 2009, pp. 137-150.

Sadan, Joseph, "Hārūn al-Rashīd and the Brewer: Preliminary Remarks on the Adab of the Elite versus Hikāyāt", en Shimon Ballas y Reuven Snir (eds.), Studies in Canonical and Popular Arabic Literature, Toronto, York Press, 1998, pp. 1-22.

Al-Šayzārī, 'Abd al-Raḥmān b. Nașr, al-Ị̄̂āh fì asrār al-nikāh, Aḥmad Farīd al-Mazīdī (ed.), Beirut, Dār al-Kutub al-'Ilmiyya, 2002: La sexualidad árabe e islámica medieval a través de la traducción del Kitāb al-īẹāh fì asrār al-nikāh de al-Šayzarī, Miguel Ángel Lucena Romero (trad. y estudio), tesis doctoral, Granada, Universidad de Granada, 2018.

Shatzmiller, Maya, Labour in the Medieval Islamic World, Leiden, E. J. Brill, 1994.

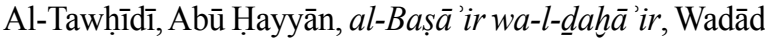
al-Qāḍ̄i (ed.), Beirut, Dār Șādir, 1988, 10 vols.

Al-Tīfāšì, Aḥmad, Nuzhat al-albāb fì mā lā yuğad fì kitāb,
Ğamāl Ğum 'a (ed.), London-Cyprus, Riad El-Rayyes Books, 1992: Esparcimiento de corazones, Ignacio Gutiérrez de Terán (trad.), Madrid, Gredos, 2003.

Al-Tirmid̄ī, Muhammad, al-Ǧāmi al-kabīr, Baššār 'Awwād Ma rūf (ed.), Beirut, Dār al- Garb al-Islāmī, 1996, 6 vols., vol. 2.

Yāqūt al-Ḥamawī, Mu 'ğam al-buldān, Beirut, Dar Șādir, 1977, 5 vols., vol. 1.

Al-Zağğālī, Abū Yahyà, Amtāāl al- 'awāmm fỉ l-Andalus li-Abì Yahyà al-Zăğgāà (617-694/1220-1294), Muhammad b. Šarīfa/Bencherifa (ed.), Fez, Manšūrāt Wizārat al-Taqāfa wa-1-Ta līm, 1971, 2 vols, vol. 2: Estudio dialectológico y lexicológico del refranero andalusí de Abu Yahyà Azzajjali, Ahmed-Salem Ould Mohamed Baba, Zaragoza, Universidad de Zaragoza, Área de Estudios Árabes e Islámicos, 1999.

Al-Zamahšarīi, Maḥmūd b. 'Umar, Rabī' al-abrār wa-nușūṣ al-ahbār, 'Abd al-Amīr Muhannā (ed.), Beirut, Manšūrāt Mu assasat al-A 'lamī li-1-Maṭbū' āt, 1992, 5 vols. 